\title{
Confined local oxygen gas promotes electrochemical water oxidation to hydrogen peroxide
}

Xia, Chuan; Back, Seoin; Ringe, Stefan; Chen, Fanhong; Sun, Xiaoming; Siahrostami, Samira; Chan, Karen; Wang, Haotian

Published in:

Nature Catalysis

Link to article, DOI:

10.1038/s41929-019-0402-8

Publication date:

2020

Document Version

Peer reviewed version

Link back to DTU Orbit

Citation (APA):

Xia, C., Back, S., Ringe, S., Chen, F., Sun, X., Siahrostami, S., Chan, K., \& Wang, H. (2020). Confined local oxygen gas promotes electrochemical water oxidation to hydrogen peroxide. Nature Catalysis, 3, 125-134. https://doi.org/10.1038/s41929-019-0402-8

\section{General rights}

Copyright and moral rights for the publications made accessible in the public portal are retained by the authors and/or other copyright owners and it is a condition of accessing publications that users recognise and abide by the legal requirements associated with these rights.

- Users may download and print one copy of any publication from the public portal for the purpose of private study or research.

- You may not further distribute the material or use it for any profit-making activity or commercial gain

- You may freely distribute the URL identifying the publication in the public portal 


\section{Confined local oxygen gas promotes electrochemical water oxidation to hydrogen peroxide}

Chuan $\mathrm{Xia}^{\mathrm{a}, \mathrm{b}}+$ Seoin Back ${ }^{\mathrm{c}}$, Stefan Ringe ${ }^{\mathrm{c}}+$, Kun Jiang ${ }^{\mathrm{d}}$, Fanhong Chen ${ }^{\mathrm{e}}$, Xiaoming Sun ${ }^{\mathrm{e}}$, Samira Siahrostami ${ }^{\mathrm{f}, *}$, Karen Chan $^{\mathrm{g}, *}$, and Haotian Wang $\mathrm{g}^{\mathrm{a}, \mathrm{h} *}$

${ }^{a}$ Department of Chemical and Biomolecular Engineering, Rice University, Houston, TX 77005, United States

${ }^{b}$ Smalley-Curl Institute, Rice University, Houston, TX 77005, United States

'SUNCAT Center for Interface Science and Catalysis, Department of Chemical Engineering, Stanford University, Stanford, CA 94305, USA

${ }^{d}$ School of Mechanical Engineering, Shanghai Jiaotong University, Shanghai 200240,

China

'State Key Laboratory of Chemical Resource Engineering, College of Energy, and Beijing Advanced Innovation Centre for Soft Matter Science and Engineering, Beijing University of Chemical Technology, 100029 Beijing, China

${ }^{f}$ Department of Chemistry, University of Calgary, 2500 University Drive NW, Calgary, Alberta, Canada T2N 1 N4

${ }^{g}$ Department of Physics, Technical University of Denmark, Kongens Lyngby, Denmark 2800

${ }^{h}$ Canadian Institute for Advanced Research, Toronto, Ontario M5G 1M1, Canada

†contributed equally

*corresponding authors

E-mail: samira.siahrostami@ucalgary.ca; kchan@fysik.dtu.dk; htwang@rice.edu 


\begin{abstract}
Electrochemical two-electron water oxidation is a promising route for renewable and on-site $\mathrm{H}_{2} \mathrm{O}_{2}$ generation as an alternative to the anthraquinone process. However, it is currently restricted by low selectivity due to strong competition from the traditional fourelectron oxygen evolution reaction, as well as large overpotential and low production rates. Here we report an interfacial engineering approach, where by coating the catalyst with hydrophobic polymers we confine in-situ produced $\mathrm{O}_{2}$ gas to tune the water oxidation reaction pathway. Using carbon catalysts as a model system, we show a significant increase of the intrinsic $\mathrm{H}_{2} \mathrm{O}$-to- $\mathrm{H}_{2} \mathrm{O}_{2}$ selectivity and activity compared to that of the pristine catalyst. The maximal $\mathrm{H}_{2} \mathrm{O}_{2}$ Faradaic efficiency was enhanced by 6-fold to $66 \%$ with an overpotential of $640 \mathrm{mV}$, under which $\mathrm{H}_{2} \mathrm{O}_{2}$ production rate of $23.4 \mu \mathrm{mol} \mathrm{min} \mathrm{m} \mathrm{cm}^{-2}(75.2$ $\mathrm{mA} \mathrm{cm}{ }^{-2}$ partial current) was achieved. This approach was successfully extended to nickel metal, demonstrating the wide applicability of our local gas confinement concept.
\end{abstract}


Hydrogen peroxide $\left(\mathrm{H}_{2} \mathrm{O}_{2}\right)$ is one of the most important fundamental chemicals in modern chemical engineering industry as well as energy and environmental applications, with an annual global demand of about 4 million tons ${ }^{1-6}$. It is currently produced through the energy-demanding and waste-intensive anthraquinone cycling process ${ }^{7}$, which is only economically viable on a relatively large scale and relies heavily on transportation and storage of unstable and hazardous bulk $\mathrm{H}_{2} \mathrm{O}_{2}$ solutions ${ }^{8}$. Using renewable electricity for on-site $\mathrm{H}_{2} \mathrm{O}_{2}$ generation via electrocatalytic processes has recently emerged as a promising alternative to traditional method ${ }^{9-14}$, with significant advantages including ambient reaction conditions, renewable energy source without fossil fuels, and green precursors such as water and air. As the oxidation state of oxygen $(-1)$ in $\mathrm{H}_{2} \mathrm{O}_{2}$ sits between molecular oxygen and water, there are two possible ways for electrochemical $\mathrm{H}_{2} \mathrm{O}_{2}$ generation: One starts from $\mathrm{O}_{2}$ via the two-electron oxygen reduction reaction (2e--ORR); the other starts from $\mathrm{H}_{2} \mathrm{O}$ via the $2 \mathrm{e}^{-}$water oxidation reaction $\left(2 \mathrm{e}^{-}-\mathrm{WOR} ; \mathrm{E}^{\mathrm{o}}=1.76 \mathrm{~V}\right.$ vs. normal hydrogen electrode; NHE) ${ }^{13}$. Both $2 \mathrm{e}^{-}$pathways however compete with their otherwise $4 \mathrm{e}^{-}$ counterparts towards $\mathrm{H}_{2} \mathrm{O}$ and $\mathrm{O}_{2}$ respectively. While exciting progress has been made in developing highly selective catalysts for ORR towards $\mathrm{H}_{2} \mathrm{O}_{2}$ instead of $\mathrm{H}_{2} \mathrm{O}^{9-11,15,16}$, there are very few known catalysts which can selectively and actively oxidize $\mathrm{H}_{2} \mathrm{O}$ into $\mathrm{H}_{2} \mathrm{O}_{2}$ with stable performances ${ }^{12,13,17,18}$. Most of reported water oxidation catalysts, such as metal oxides, hydroxides, chalcogenides, nitrides, and carbon materials, showed exclusive oxygen evolution reaction (OER) under water oxidation potentials ${ }^{19-25}$. Steering the regular $4 \mathrm{e}^{-}-\mathrm{WOR}$ pathway towards the unconventional $2 \mathrm{e}^{-}$pathway therefore becomes both fundamentally interesting for mechanistic understanding, and technologically important as a promising anode route for $\mathrm{H}_{2} \mathrm{O}_{2}$ generation. In addition, the development of high- 
performance $2 \mathrm{e}^{-}-\mathrm{WOR}$ catalysts, coupled with the corresponding $2 \mathrm{e}^{-}-\mathrm{ORR}$ cathode catalysts, will enable an efficient $\mathrm{H}_{2} \mathrm{O}_{2}$ electrosynthetic cell where $\mathrm{H}_{2} \mathrm{O}_{2}$ can be selectively generated from both electrodes.

The key in tuning the WOR pathway relies on the interaction between catalytic surface and $\mathrm{O}$ intermediates, such as ${ }^{*} \mathrm{O},{ }^{*} \mathrm{OH}$, and ${ }^{*} \mathrm{OOH}^{13,26}$. In general, a proper interaction is desired for selective and active 2e-WOR: a too-strong $\mathrm{OH}$ binding could further oxidize $* \mathrm{OH}$ to ${ }^{*} \mathrm{O}$ and ${ }^{*} \mathrm{OOH}$, finishing the complete $4 \mathrm{e}^{-}$oxidation pathway towards $\mathrm{O}_{2}$; a too-weak binding will lead to high kinetic barriers of water dissociation, dramatically slowing down the reaction rate ${ }^{13}$. Previous efforts have been focused on screening catalytic materials with proper electronic structures, such as wide band-gap metal oxides $\left(\mathrm{ZnO}, \mathrm{WO}_{3}, \mathrm{SnO}_{2}, \mathrm{TiO}_{2}, \mathrm{BiVO}_{4} \text { and } \mathrm{CaSnO}_{3}\right)^{13,14,18,27}$. While promising progress has been made in improving $\mathrm{H}_{2} \mathrm{O}_{2}$ selectivity, the state-of-the-art catalysts still present significant overpotentials of more than $1 \mathrm{~V}$ to deliver relatively low $\mathrm{H}_{2} \mathrm{O}_{2}$ partial currents $\left.(\sim 10 \mathrm{~mA} \mathrm{~cm})^{-2}\right)^{13,14,18,27}$. Unlike these materials' screening method for improving the performance of $2 \mathrm{e}^{-}-\mathrm{WOR}$, we propose to use locally generated $\mathrm{O}_{2}$ gas, from the catalysts' surface, to effectively regulate the interaction with $\mathrm{O}$ intermediates and thus change the reaction selectivity and activity. Under a positive enough potential, most of the water oxidation catalysts will continuously evolve $\mathrm{O}_{2}$ with their active sites refreshed after the generated $\mathrm{O}_{2}$ gas bubbles away ${ }^{28}$. We hypothesize that, if those generated $\mathrm{O}_{2}$ gas can be confined around the active sites, the accumulated $\mathrm{O}_{2}$ molecules could further interact with the catalysts' surface or the intermediate $\mathrm{O}$ species, and thus be able to tune the intermediate binding strength for completely different reaction pathways. 
Here we report an interfacial engineering approach in which we trap in-situ produced $\mathrm{O}_{2}$ gas close to active sites by coating the catalyst surface with hydrophobic polymers. Using OER-selective carbon catalysts as a model system, we observed a significant increase of the intrinsic $\mathrm{H}_{2} \mathrm{O}-$ to- $\mathrm{H}_{2} \mathrm{O}_{2}$ selectivity and activity once generated $\mathrm{O}_{2}$ gas was confined to the surface. The $\mathrm{H}_{2} \mathrm{O}_{2}$ selectivity was enhanced by 6-fold from only $11 \%$ on pristine carbon to a maximal of $66 \%$. An impressive $\mathrm{H}_{2} \mathrm{O}_{2}$ production rate of 23.4 $\mu \mathrm{mol} \mathrm{min} \mathrm{cm}^{-1}\left(75.2 \mathrm{~mA} \mathrm{~cm}{ }^{-2}\right.$ partial current) was achieved under a small overpotential of $640 \mathrm{mV}$, which tops the performances reported in literature. With insights from ab-initio modeling, we postulate that the locally confined $\mathrm{O}_{2}$ gas could shift the $* \mathrm{OH}$ binding on various carbon sites in the direction of improved $\mathrm{H}_{2} \mathrm{O}_{2}$ activity, through a decrease in solvation energies or a decrease in the $* \mathrm{O}$ coverage around catalytic sites. This local gas confinement approach was successfully extended to other OER-exclusive catalysts, such as nickel metal, for partial $\mathrm{H}_{2} \mathrm{O}_{2}$ generation, suggesting its wide applicability.

\section{Results}

Electrocatalytic 2e-WOR. We first select a flat carbon surface to evaluate the relationship between $\mathrm{O}_{2}$ gas confinement and $\mathrm{H}_{2} \mathrm{O}_{2}$ selectivity. Polytetrafluoroethylene (PTFE) polymer islands were deposited onto mirror-polished glassy carbon (GC) electrodes to artificially create an aerophilic surface in aqueous solutions (Fig. 1a, Methods ${ }^{29}$ using a shadow mask assisted spray-coated method. When a fixed positive potential higher than the onset of OER was applied, the PTFE islands can function as aerophilic centers around which the generated $\mathrm{O}_{2}$ gas were confined to form gas-liquid-solid triple phase boundaries

(Fig. 1a). Those locally confined $\mathrm{O}_{2}$ bubbles may in turn interact with catalytic sites and 
thus affect the $\mathrm{H}_{2} \mathrm{O}_{2}$ selectivity. With $\mathrm{O}_{2}$ gas continuously produced, the bubbles will gradually grow and eventually leave the surface when the buoyant force becomes larger than the bubble adhesive force on the catalytic surface. Therefore, under steady-state $\mathrm{O}_{2}$ evolution, the adhesive force of $\mathrm{O}_{2}$ bubbles could represent the ability of the catalyst to confine local $\mathrm{O}_{2}$ gas. By tuning the size of the PTFE patterning via a shadow mask-assisted spray coating method (Supplementary Fig. 1, Methods), we can change the adhesive force of $\mathrm{O}_{2}$ bubbles on the $\mathrm{GC}$ surface and examine the resulting $\mathrm{H}_{2} \mathrm{O}_{2}$ selectivity.

A positive potential of $2.05 \mathrm{~V}$ versus the reversible hydrogen electrode ( $v s$. RHE) was applied on three different samples as shown in Fig. 1b-g: pristine GC, GC with 300 $\mu \mathrm{m}(300-\mathrm{GC})$ and $200 \mu \mathrm{m}(200-\mathrm{GC}) \mathrm{PTFE}$ patterning. While no obvious $\mathrm{O}_{2}$ bubbles were observed on the surface of pristine GC, PTFE islands were able to accumulate the in-situ formed $\mathrm{O}_{2}$ during water oxidation process ${ }^{30}$ (Fig. 1 b and Supplementary Video 1-3). This is consistent with the different adhesive forces on different surfaces. The pristine GC demonstrates a $21.3 \mu \mathrm{N}$ adhesive force for $\mathrm{O}_{2}$ bubble with an under-electrolyte bubble contact of $156.4^{\circ} \pm 1.6^{\circ}$ (Fig. 1h). In a sharp contrast, 300-GC and 200-GC offer a much stronger adhesive force of 80.7 and $106.0 \mu \mathrm{N}$, respectively, leading to stronger confinements of local gaseous $\mathrm{O}_{2}$. Consistently, the under-electrolyte $\mathrm{O}_{2}$ bubble contact angles of 300-GC and 200-GC (inset of Fig. 1h) decrease to $143.0^{\circ} \pm 0.8^{\circ}$ and $118.0^{\circ} \pm$ $2.1^{\circ}$, respectively, indicating the enhanced aerophilicity of the catalytic surfaces. The different local $\mathrm{O}_{2}$ confinements result in different $\mathrm{H}_{2} \mathrm{O}_{2}$ activities and selectivity. The pristine $\mathrm{GC}$ presents an intrinsic $\mathrm{H}_{2} \mathrm{O}_{2}$ selectivity of $7.3 \%$ on carbon materials, which was gradually improved to $9.0 \%$ on $300-\mathrm{GC}$ and further to $11.4 \%$ on $200-\mathrm{GC}$ with similar trend to the adhesive force (Fig. 1i). This phenomenon reveals to us that the intrinsic $\mathrm{H}_{2} \mathrm{O}_{2}$ 
selectivity of carbon catalyst could be positively affected by the strength of local $\mathrm{O}_{2}$ confinement.
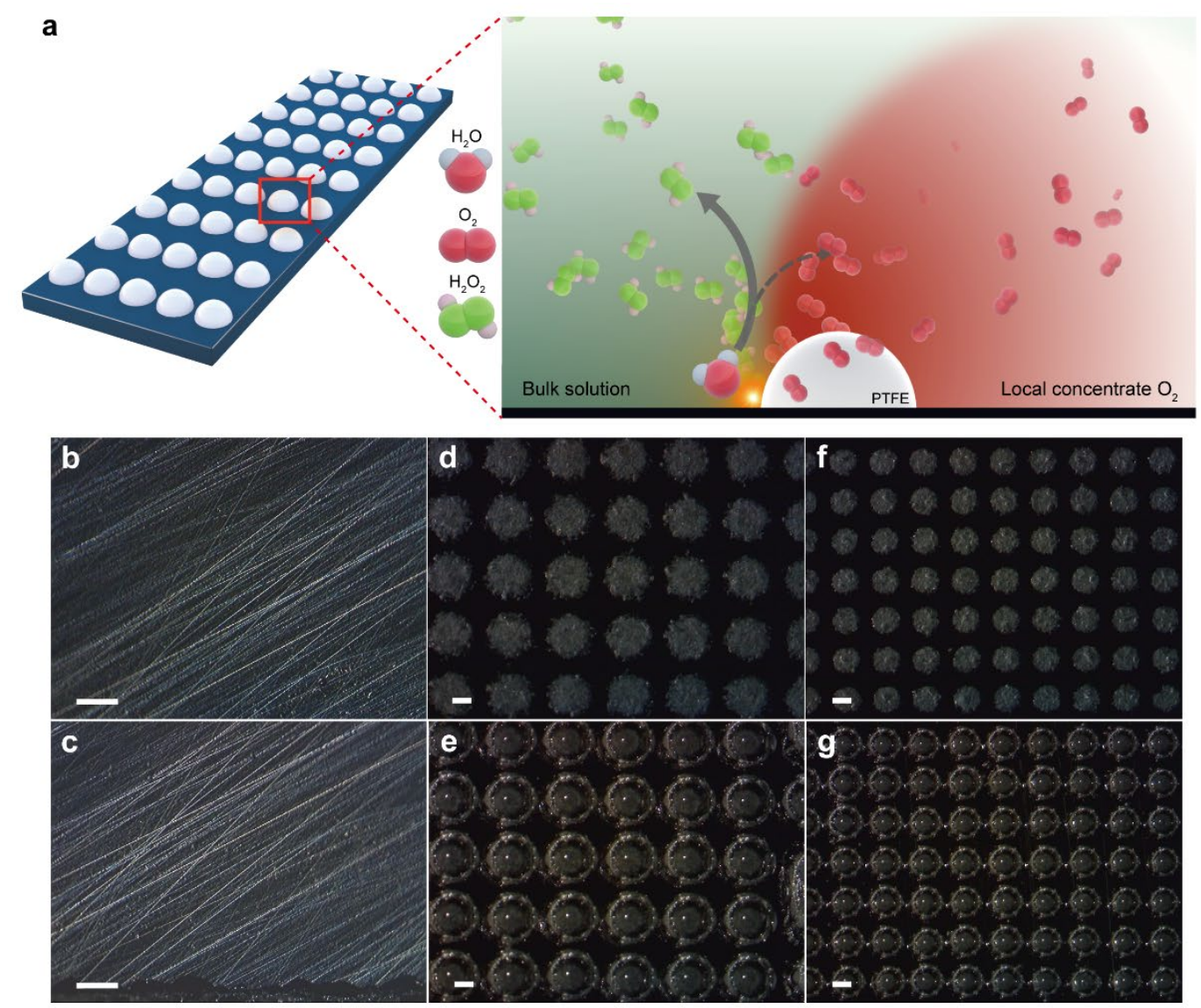

h

i
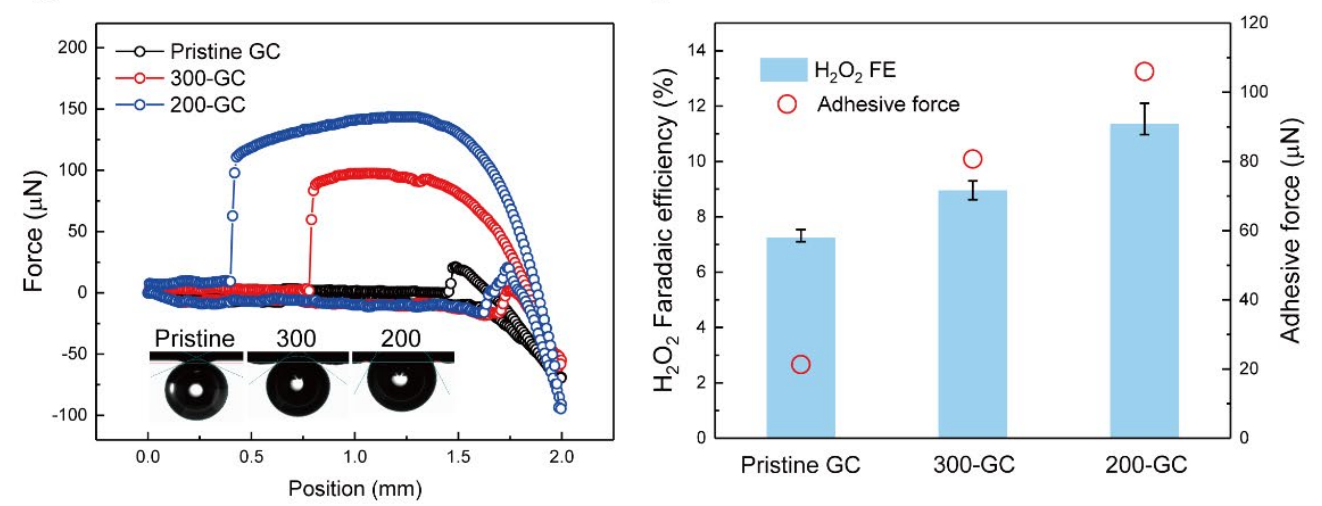

Fig. 1 | Experimental observation of local product concentration effect. a, A schematic showing the assumed possible reaction pathway tuning by local concentrate product. b-g, Digital photos for pristine and PTFE patterned $\mathrm{GC}$ in $1.0 \mathrm{M} \mathrm{Na}_{2} \mathrm{CO}_{3}$ electrolyte. b-c, pristine GC recorded at open circuit and $2.05 \mathrm{~V}$ vs. RHE, respectively. d-e, 300-GC recorded at open circuit and $2.05 \mathrm{~V} v s$. RHE, respectively. f-g, 200-GC recorded at open 
circuit and $2.05 \mathrm{~V} v s$. RHE, respectively. It demonstrates that the pristine GC cannot hold any $\mathrm{O}_{2}$ bubble on its surface, however, the PTFE patterned GC is able to concentrate the gaseous $\mathrm{O}_{2}$ around the catalytic surface. Scale bars: b-g $300 \mu \mathrm{m} . \mathbf{h}, \mathrm{O}_{2}$ gas bubble adhesive force measurements for pristine GC, 300-GC and 200-GC electrode, demonstrating enhanced $\mathrm{O}_{2}$ adhesive force of GC surface after PTFE loading. The insets show the $\mathrm{O}_{2}$ bubble contact angles under electrolyte. $\mathbf{i}$, The $\mathrm{H}_{2} \mathrm{O}_{2}$ Faradaic efficiency of pristine GC, $300-\mathrm{GC}$ and $200-\mathrm{GC}$ catalyst in $1.0 \mathrm{M} \mathrm{Na}_{2} \mathrm{CO}_{3}$ electrolyte at $2.05 \mathrm{~V} v$ s. RHE, where a monotonic increase of $\mathrm{H}_{2} \mathrm{O}_{2} \mathrm{FE}$ was observed with increasing of $\mathrm{O}_{2}$ bubble adhesive force. The applied potential of GC should be less than $2.1 \mathrm{~V} v s$. RHE in order to prevent glassy carbon electrode damage by oxidation during long operation ${ }^{31}$. Thus, $2.05 \mathrm{~V} v s$. RHE was chosen for water oxidation measurements. The error bars represent three independent samples.

To elaborate the possible reaction mechanisms and to further amplify the $\mathrm{O}_{2}$ confinement effect for improved $\mathrm{H}_{2} \mathrm{O}_{2}$ generation performance, a systematic control of the loading of PTFE polymer coating on a three-dimensional porous carbon fiber paper (CFP) electrode was investigated. The polymer loading can be precisely controlled by changing the concentration of PTFE solution during the dip-coating process, where the 5\% (CFP5\%), 20\% (CFP-20\%), and 60\% (CFP-60\%) PTFE solutions result in a PTFE mass loading (compared to that of CFP) of $12 \%, 55 \%$ and $150 \%$, respectively (Methods). Scanning electron microscopy (SEM) analysis suggests that PTFE nanoflakes can be uniformly deposited on the surfaces of carbon fibers (Supplementary Fig. 2a-b), providing sufficient triple phase boundaries and gas confinement for two-electron water oxidation. As expected, the gas adhesive force gradually increased with increased PTFE coating, with consistently decreased under-electrolyte $\mathrm{O}_{2}$ and increased in-air water contact angles (Supplementary Fig. 3), which we suggest to have a direct impact on the water oxidation catalytic activity and selectivity. First, since the PTFE coating repels water and leads to a lower electrochemical surface area (ECSA, Supplementary Fig. 4), the overall geometric current densities were gradually decreased compared to pristine CFP (Fig. 2a). However, the $\mathrm{H}_{2} \mathrm{O}_{2}$ 
selectivity showed a monotonic enhancement with increased PTFE coating (Fig. 2b). The peak $\mathrm{H}_{2} \mathrm{O}_{2}$ Faradaic efficiency (FE) of pristine CFP is $c a$. $10 \%$, but increased to $23 \%, 31 \%$ and $66 \%$ by CFP- $5 \%$, CFP- $20 \%$ and CFP-60\% samples, respectively, which represents a maximal 6-fold enhancement in $\mathrm{H}_{2} \mathrm{O}_{2}$ selectivity (Supplementary Fig. 5 and 6). A similar trend was also observed in other electrolyte such as $1.0 \mathrm{M} \mathrm{K}_{3} \mathrm{PO}_{4}$ electrolyte $(\mathrm{pH}=13.18$; Supplementary Fig. 7a). We employed gas chromatography to quantify the FEs of gas products during water oxidation. Combining the gas chromatography and $\mathrm{H}_{2} \mathrm{O}_{2}$ titration results, we got an overall ca. $100 \%$ FE from $\mathrm{H}_{2} \mathrm{O}$-to- $\mathrm{O}_{2}$ and $\mathrm{H}_{2} \mathrm{O}-$ to- $-\mathrm{H}_{2} \mathrm{O}_{2}$ processes (Supplementary Fig. 7b) with negligible $\mathrm{CO}$ or $\mathrm{CO}_{2}$ from possible carbon oxidation (lower than the detection limit of the thermal conductivity detector), suggesting that the measured electrocatalytic anodic current exclusively stems from water oxidation reactions and the CFP is stable under our operation conditions. In addition, no obvious morphology evolution could be observed for PTFE modified CFP catalyst after electrochemical measurements (Supplementary Fig. 2c-d). The $\mathrm{H}_{2} \mathrm{O}_{2}$ evolution onset potential (defined as the potential where the $\mathrm{H}_{2} \mathrm{O}_{2}$ concentration reaches 1 ppm after 10 mins electrolysis) of CFP-60\% sample was measured to be only $290 \mathrm{mV}$, which is among the best compared to previous catalysts. ${ }^{13,14}$ More importantly, in contrast to previous oxide catalysts which require large positive potentials ( $>3 \mathrm{~V} v s$. RHE) to deliver $\mathrm{H}_{2} \mathrm{O}_{2}$ current densities of $c a$. $10 \mathrm{~mA} \mathrm{~cm}{ }^{-2}$, the $\mathrm{H}_{2} \mathrm{O}$-to- $\mathrm{H}_{2} \mathrm{O}_{2}$ partial current on our CFP- $60 \%$ catalyst ramps up quickly to $75.2 \mathrm{~mA} \mathrm{~cm}^{-2}\left(23.4 \mu \mathrm{mol} \mathrm{min} \mathrm{cm}^{-2}\right)$ with a maximal $66 \%$ selectivity under only $2.4 \mathrm{~V}$ vs. RHE potential, which represents a record-high performance compared to existing catalysts (Fig. 2c). 
a
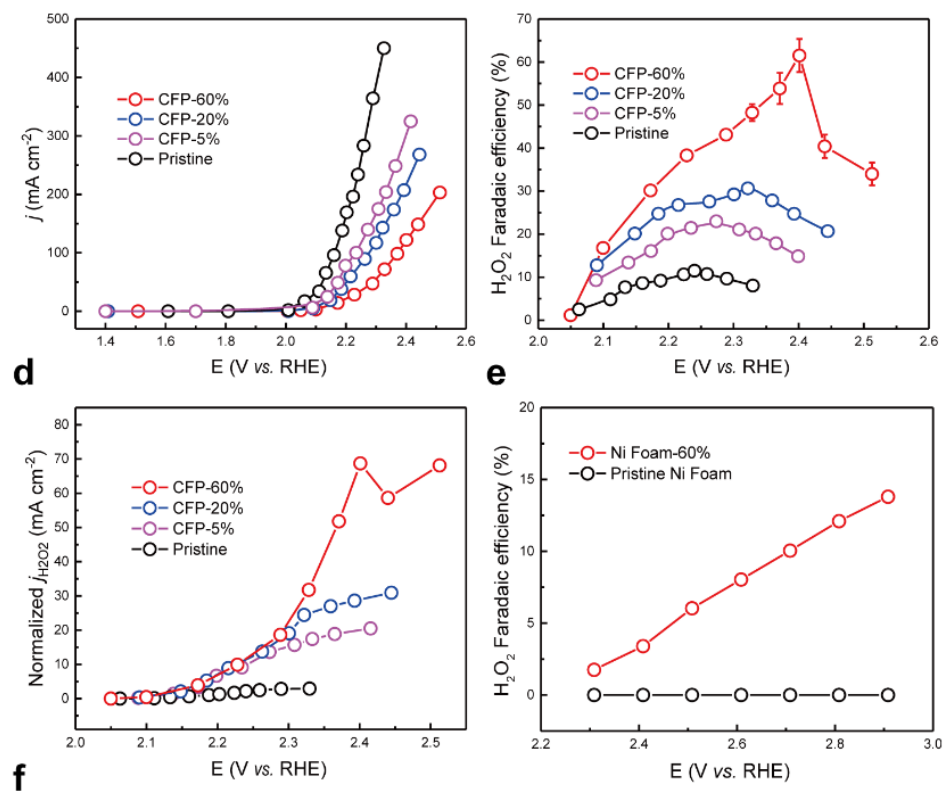

C

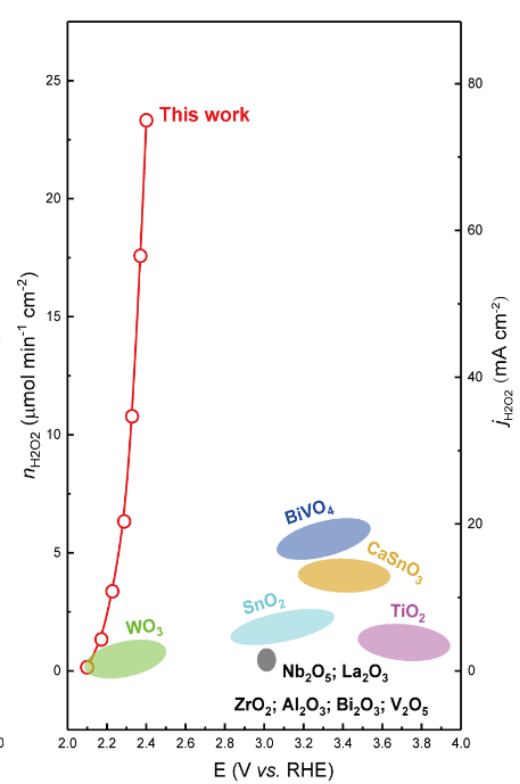

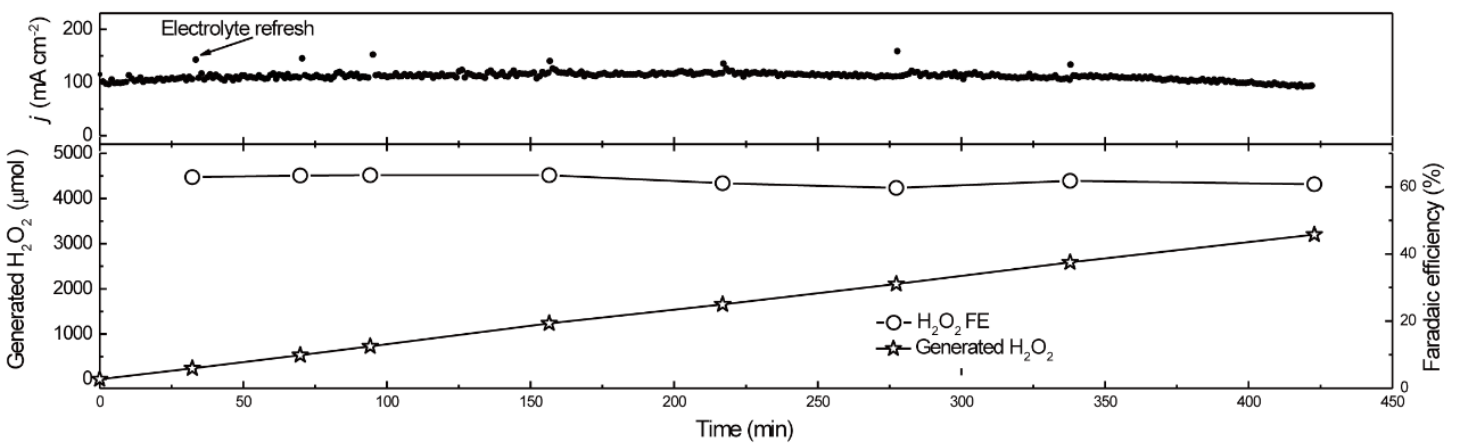

Fig. 2 | Water oxidation performances on $\mathrm{CFP}$ and $\mathrm{Ni}$ based catalysts in $1.0 \mathrm{M} \mathrm{Na}_{2} \mathrm{CO}_{3}$, pH 11.96. a, The overall current densities of the pristine CFP, CFP-5\%, CFP- $20 \%$ and CFP- $60 \%$ catalysts. b, $\mathrm{H}_{2} \mathrm{O}_{2}$ Faradaic efficiencies on pristine CFP, CFP-5\%, CFP- $20 \%$ and CFP- $60 \%$ at different applied potentials. The highest Faradaic efficiency reaches $66 \%$. The error bars represent three independent samples. c, $\mathrm{H}_{2} \mathrm{O}_{2}$ generation rates of CFP- $60 \%$ catalyst under different applied potential. The typically reported two-electron water oxidation catalysts, including $\mathrm{BiVO}_{4}, \mathrm{CaSnO}_{3}, \mathrm{WO}_{3}, \mathrm{SnO}_{2}, \mathrm{TiO}_{2}, \mathrm{Nb}_{2} \mathrm{O}_{5}, \mathrm{La}_{2} \mathrm{O}_{3}, \mathrm{ZrO}_{2}$, $\mathrm{Al}_{2} \mathrm{O}_{3}, \mathrm{Bi}_{2} \mathrm{O}_{3}$ and $\mathrm{V}_{2} \mathrm{O}_{5}{ }^{13,18,27}$, are also listed for comparison. d, ECSA-normalized $\mathrm{H}_{2} \mathrm{O}_{2}$ production partial current density versus potential on pristine CFP, CFP-5\%, CFP-20\% and CFP- $60 \%$. e, $\mathrm{H}_{2} \mathrm{O}_{2}$ Faradaic efficiencies on pristine Ni foam and $60 \%$ PTFE solution modified Ni foam (Ni Foam-60\%). Note that the potentials for Ni-based electrode are not $i R$-compensated. f, The overall current density and $\mathrm{H}_{2} \mathrm{O}_{2}$ Faradaic efficiency of CFP- $60 \%$ catalyst at $2.4 \mathrm{~V} v s$. RHE over the course of continuous electrolysis. The geometric area of the CFP- $60 \%$ electrode is $0.36 \mathrm{~cm}^{2}$.

We performed detailed experimental analysis to investigate the possible mechanism for this shift of the water oxidation pathway from $4 \mathrm{e}^{-}$to $2 \mathrm{e}^{-}$. First, to exclude 
possible contributions from $\mathrm{O}_{2}$ plasma treatment, Argon annealing, or fluorine dopant during sample preparation processes, in one control we only treated the pristine CPF using $\mathrm{O}_{2}$ plasma; in a second we annealed the pristine $\mathrm{CFP}$ at $350^{\circ} \mathrm{C}$; in a third we converted the CFP-60\% sample into fluorine-doped carbon/CFP by high temperature annealing in Argon atmosphere (Supplementary Fig. 2e-f). The three control electrodes demonstrate similar two-electron water oxidation performance as pristine CFP, with a maximal $\mathrm{H}_{2} \mathrm{O}_{2} \mathrm{FE}$ of $14.6 \%, 13.4 \%$ and $11.3 \%$, respectively (Supplementary Fig. 7c, d). Secondly, to demonstrate that the carbon site selectivity for $\mathrm{H}_{2} \mathrm{O}_{2}$ formation is not related to the specific surface deposited materials, trimethoxy $(1 \mathrm{H}, 1 \mathrm{H}, 2 \mathrm{H}, 2 \mathrm{H}$-heptadecafluorodecyl) silane was used to replace the PTFE to create the similar aerophilic surface to trap $\mathrm{O}_{2}$ gas ${ }^{32}$ (Supplementary Fig. 7e, f). After silane modification, we found that the $\mathrm{H}_{2} \mathrm{O}_{2}$ selectivity of CFP can also be significantly boosted, demonstrating that the confined $\mathrm{O}_{2}$ plays the role in promoting $\mathrm{H}_{2} \mathrm{O}_{2}$ selectivity. The above two pieces of evidence show that the carbon site selectivity is related neither to the fabrication processes nor the surface deposited materials, but could instead be directly linked to local $\mathrm{O}_{2}$ concentration.

One may, at first glance, hypothesize that the locally confined $\mathrm{O}_{2}$ gas shifts the $\mathrm{H}_{2} \mathrm{O}$-to- $\mathrm{O}_{2}$ equilibrium towards its reverse reaction $\left(\mathrm{O}_{2}-\mathrm{to}_{-}-\mathrm{H}_{2} \mathrm{O}\right)$, which potentially suppresses the $4 \mathrm{e}^{-}$path and thus as a result increases $\mathrm{H}_{2} \mathrm{O}_{2}$ selectivity. However, this equilibrium factor can be ruled out by comparing the intrinsic activities of carbon sites with ECSA normalization (Fig. 2d and Supplementary Fig. 4): While 1) PTFE modified CFP catalysts presented higher $\mathrm{H}_{2} \mathrm{O}_{2}$ partial currents (more than an order of magnitude) compared to pristine CFP under different applied potentials, indicating their dramatically improved intrinsic $\mathrm{H}_{2} \mathrm{O}$-to- $\mathrm{H}_{2} \mathrm{O}_{2}$ catalytic activities; 2) the intrinsic $\mathrm{H}_{2} \mathrm{O}$-to- $\mathrm{O}_{2}$ activity was 
similar compared to pristine carbon (Supplementary Fig. 8a). Since the pressure/activity of locally confined $\mathrm{O}_{2}$ gas does not directly impact the $\mathrm{H}_{2} \mathrm{O}-$ to- $\mathrm{H}_{2} \mathrm{O}_{2}$ equilibrium, and on the other hand the $4 \mathrm{e}^{-}$OER equilibrium was not obviously inhibited, we conclude that the enhanced $\mathrm{H}_{2} \mathrm{O}_{2}$ generation performances in our carbon catalyst systems are not due to the simple chemical equilibrium shift effect. We also note that the different PTFE-coated CFP samples showed quite similar $\mathrm{H}_{2} \mathrm{O}_{2}$ intrinsic activities within a certain potential window until they diverge at large overpotentials, where $\mathrm{O}_{2}$ bubbles evolve violently, which further supports our hypothesis that increased confinement of $\mathrm{O}_{2}$ gas at the interface has a positive correlation with $\mathrm{H}_{2} \mathrm{O}_{2}$ activity. Furthermore, similar $\mathrm{H}_{2} \mathrm{O}-$ to- $\mathrm{H}_{2} \mathrm{O}_{2}$ performance was obtained using pristine CFP catalyst in Ar, Air and $\mathrm{O}_{2}$ saturated electrolyte (Supplementary Fig. 8b), eliminating the possible contributions from dissolved $\mathrm{O}_{2}$ in electrolyte. These results, taken together, suggest that the locally accumulated $\mathrm{O}_{2}$ gas molecules may directly interact with carbon active sites or reaction intermediates, which as a result significantly shifts the water oxidation pathway from $4 \mathrm{e}^{-}$of $\mathrm{O}_{2}$ to $2 \mathrm{e}^{-}$of $\mathrm{H}_{2} \mathrm{O}_{2}$.

We found that this concept of confining local $\mathrm{O}_{2}$ gas to control the selectivity towards $\mathrm{H}_{2} \mathrm{O}_{2}$ can be successfully extended to other catalytic materials beyond carbon. As an example, we investigated Ni metal foam, which has been established as a highly active, OER-exclusive catalyst ${ }^{33,34}$. As shown in Fig. 2e, we confirmed that while pristine Ni foam did not generate detectable $\mathrm{H}_{2} \mathrm{O}_{2}$, PTFE-coated Ni foam (Methods) achieves a $\mathrm{H}_{2} \mathrm{O}_{2} \mathrm{FE}$ of $13.8 \%$ (20 mA cm ${ }^{-2} \mathrm{H}_{2} \mathrm{O}_{2}$ partial current) at an applied potential of $2.9 \mathrm{~V} v s$. RHE, which has never been observed in Ni metal catalysts before.

Lastly, as performance stability is a common concern in previously reported $\mathrm{H}_{2} \mathrm{O}$ to- $\mathrm{H}_{2} \mathrm{O}_{2}$ catalysts due to their very high overpotentials ${ }^{35}$, we performed 
chronoamperometry on our CFP- $60 \%$ catalyst by holding a $2.4 \mathrm{~V} v s$. RHE potential where $\mathrm{H}_{2} \mathrm{O}_{2}$ selectivity is maximal (Fig. 2f). The current density showed negligible changes during the course of stability test. Around $61 \% \mathrm{H}_{2} \mathrm{O}_{2}$ selectivity was still maintained after 7-hour continuous electrolysis, demonstrating the good stability of the catalyst over long operation period (Supplementary Fig. 2c-d). However, we should emphasize here that more works need to be done to extend the stability from the order of 10 hours to thousands of hours for future's possible application. This could be addressed by incorporating other catalytic materials with confined $\mathrm{O}_{2}$ effects to further lower the overpotential for highperformance $\mathrm{H}_{2} \mathrm{O}_{2}$ generation.
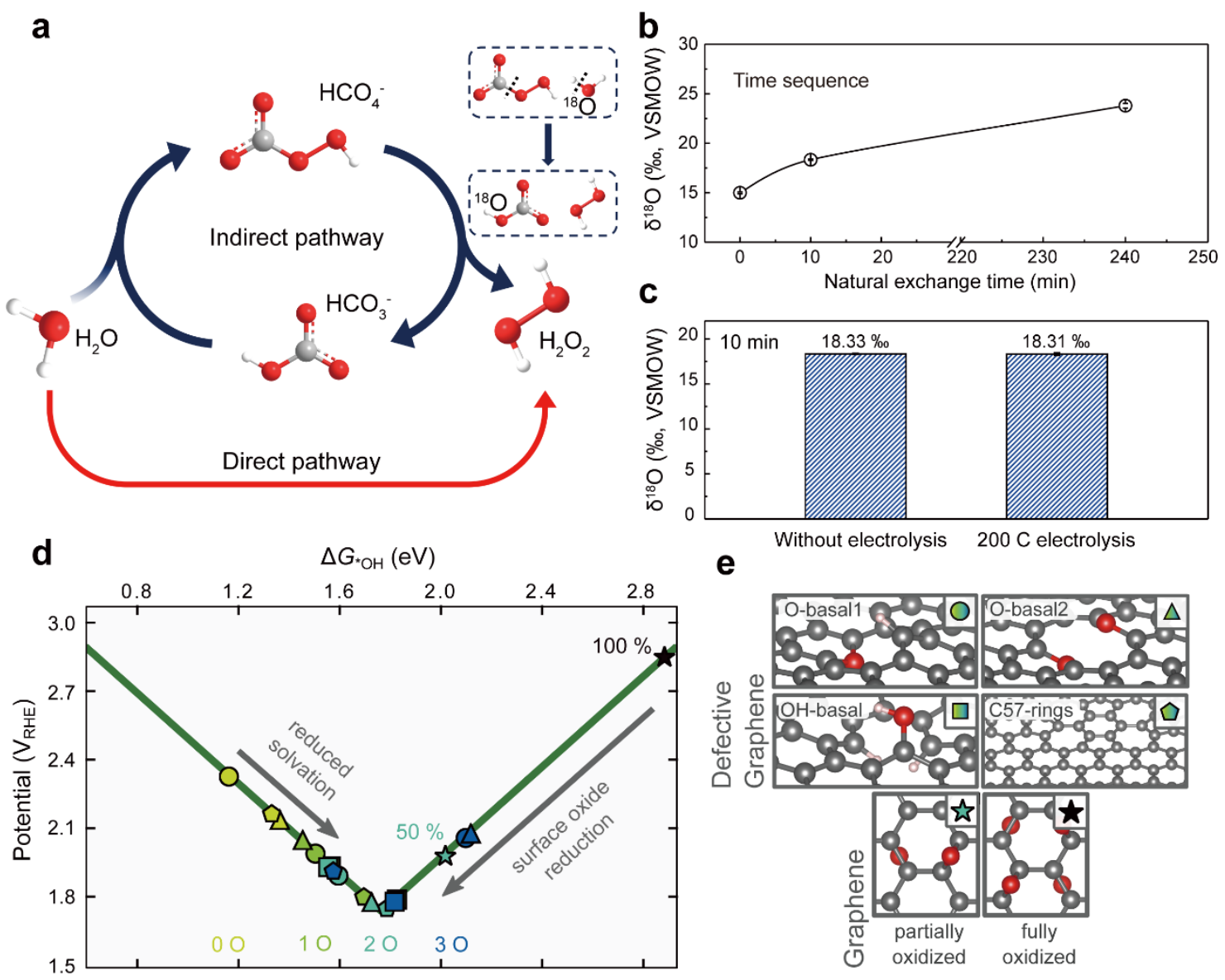

Fig. 3 | Possible mechanisms. a, Two different reaction pathways for catalytic twoelectron water oxidation. $\mathbf{b},{ }^{18} \mathrm{O}$ isotope abundance in quickly dried (within 2 mins, Methods) $1.0 \mathrm{M} \mathrm{Na}_{2} \mathrm{CO}_{3}$ electrolyte with varied isotope exchange time between $\mathrm{Na}_{2} \mathrm{CO}_{3}$ 
solute and DI water. The analytical precision $(1 \sigma)$ is $0.05 \%$ for $\delta^{18} \mathrm{O}$, and the values are reported as standard $\delta$ notation with respect to $\mathrm{V}-\mathrm{SMOW} . \mathbf{c},{ }^{18} \mathrm{O}$ isotope abundance in quickly dried $1.0 \mathrm{M} \mathrm{Na}_{2} \mathrm{CO}_{3}$ electrolyte with or without applied potential (2.4 V vs. RHE). The error bars in $\mathbf{b}$ and $\mathbf{c}$ represent two independent tests. d, $2 \mathrm{e}^{-}$volcano plot of $\mathrm{H}_{2} \mathrm{O}$ oxidation as a function of the $* \mathrm{OH}$ binding energy $(\Delta \mathrm{G} * \mathrm{OH})$. The data points depict $* \mathrm{OH}$ binding energies on defected graphene sheets (circles, pentagons, triangles and squares) as well as partially (50\%) and fully oxidized graphene sheets (stars) (without correction for solvation effects) and are schematically drawn in (e). In case of the defected structures, four different typical defects were considered as well as different coverages of oxygen atoms in the vicinity of the active site indicated by yellow (low coverage, no ${ }^{*} \mathrm{O}$ in the vicinity, structures shown in panel e) to blue (high coverage, $3 * \mathrm{O}$ in the vicinity) color scale. Arrows indicate potential external driving forces which likely influence the $\mathrm{H}_{2} \mathrm{O}_{2}$ selectivity by decreasing solvation stabilization due to the creation of water-poor oxygen bubbles or by reducing the degree of surface oxidation.

Proposed possible mechanisms. Previous two-electron water oxidation studies on oxides electrocatalysts suggested an indirect, percarbonate-involved mechanism (Fig. 3a). ${ }^{13,36,37}$ Firstly, the percarbonate species, such as $\mathrm{HCO}_{4}^{-}$and $\mathrm{C}_{2} \mathrm{O}_{6}{ }^{2-}$ are generated by electrochemical $\mathrm{HCO}_{3}{ }^{-}$oxidation on the electrode at a high applied potential. Subsequently, the percarbonate species are hydrolyzed by $\mathrm{H}_{2} \mathrm{O}$ in the electrolyte, resulting in the formation of $\mathrm{H}_{2} \mathrm{O}_{2}$ and $\mathrm{HCO}_{3}{ }^{-}$. Based on this mechanism, a significant promotion effect on $\mathrm{H}_{2} \mathrm{O}_{2}$ formation was observed using bicarbonate electrolyte, e.g. $\mathrm{KHCO}_{3}{ }^{13,36}$. However, in stark contrast to previous reports, the two-electron water oxidation performance of the CFP-60\% catalyst is much better in $1.0 \mathrm{M} \mathrm{Na}_{2} \mathrm{CO}_{3}$ electrolyte compared with that in 1.0 $\mathrm{M} \mathrm{NaHCO}_{3}$ (Supplementary Fig. 9). No promotion effect could be observed using bicarbonate electrolyte in our case, indicating a different mechanism for our carbon catalyst systems. To further explore whether percarbonate intermediates are a possible reaction pathway, we performed oxygen isotope experiments. In our as-obtained $\mathrm{Na}_{2} \mathrm{CO}_{3}$, the abundance of ${ }^{18} \mathrm{O}$ is different compared with that in DI water. The as-obtained $\mathrm{Na}_{2} \mathrm{CO}_{3}$ has a $\delta^{18} \mathrm{O}$ of $14.99 \%$. As shown in Fig. 3b, after the fresh preparation of $1.0 \mathrm{M} \mathrm{Na} \mathrm{CO}_{3}$ 
solution, we observed a natural isotope oxygen exchange with increased $\delta^{18} \mathrm{O}$ in $\mathrm{Na}_{2} \mathrm{CO}_{3}$ to $18.33 \%$ ( $10 \mathrm{~min})$ and $23.79 \% \mathrm{o}(2 \mathrm{~h})$. Therefore, within $10 \mathrm{mins}$ during which the natural exchange does not reach equilibrium, if the percarbonate is the dominant reaction intermediates, we should be able to observe an ${ }^{18} \mathrm{O}$ isotope difference between the electrolyzed $\mathrm{Na}_{2} \mathrm{CO}_{3}$ and the bare one, considering the violent interaction and chemical bond reconfiguration between the $\mathrm{HCO}_{4}^{-}$intermediate and $\mathrm{H}_{2} \mathrm{O}$ (Fig. 3a). The isotope ratio mass spectrometry was employed to monitor the ${ }^{18} \mathrm{O}$ isotope in the samples, which offers an analytical precision $(1 \sigma)$ of $0.05 \%$ for $\delta^{18} \mathrm{O}$ and the values are reported as standard $\delta$ notation with respect to V-SMOW (Methods) ${ }^{38}$. After electrolysis with $200 \mathrm{C}$ passing ( 10 mins), $1 \mathrm{~mL}$ of the electrolyzed $1.0 \mathrm{M} \mathrm{Na}_{2} \mathrm{CO}_{3}$ solution was taken out, meanwhile another $1 \mathrm{~mL}$ of solution was taken from the unelectrolyzed bulk $1.0 \mathrm{M} \mathrm{Na}_{2} \mathrm{CO}_{3}$ solution. Then both of them were quickly dried in a surface dish at $100{ }^{\circ} \mathrm{C}$. Of note, the natural exchange time with the DI water was same for the unelectrolyzed and electrolyzed $\mathrm{Na}_{2} \mathrm{CO}_{3}$. As shown in Fig. 3c, the $\delta^{18} \mathrm{O}$ value for $1.0 \mathrm{M} \mathrm{Na}_{2} \mathrm{CO}_{3}$ electrolyte with and without applied potential showed negligible change (18.31\%o vs. $18.33 \%$ ). This unchanged ${ }^{18} \mathrm{O}$ abundance in $\mathrm{Na}_{2} \mathrm{CO}_{3}$ after electrolysis implies that our catalyst systems do not follow the indirect mechanism. It is most likely that the electrocatalytic formation of $\mathrm{H}_{2} \mathrm{O}_{2}$ using our carbon catalysts follows the direct pathway (Fig. 3a).

The complexity of carbon materials together with the multi-scale nature of the here observed confined $\mathrm{O}_{2}$ gas effect, makes it challenging to derive fully converged mechanistic explanations. Instead, we at this point present an ab-initio thermodynamic analysis of the complex interface and assess its qualitative contributions to the $\mathrm{H}_{2} \mathrm{O}_{2}$ product selectivity. We hope that these very initial discussions could involve 
more detailed discussions in the future. Carbon materials including both GC and CFP are complex agglomerates of graphene-like structures, and give rise to a wide range of site motifs $^{39}$; the experimentally observed catalytic activity can therefore arise from a variety of active sites ${ }^{10,40}$. For various water oxidation to $\mathrm{H}_{2} \mathrm{O}_{2}$ catalysts, theoretical onset potentials based on binding free energies of ${ }^{*} \mathrm{OH}(\Delta \mathrm{G} * \mathrm{OH})$ have shown a good correlation with experiments, suggesting $\Delta \mathrm{G} *_{\mathrm{OH}}$ to be a meaningful descriptor ${ }^{13}$. In the present work, we thus consider the $* \mathrm{OH}$ binding energies at various coverages on four structures of defected graphene (O-basal 1, O-basal 2, OH-basal and 5555-6-7777 defective) which have been shown to weakly bind $\mathrm{OH}^{*}$ and therefore are excepted to be relevant active sites in the range of water oxidation to $\mathrm{H}_{2} \mathrm{O}_{2}{ }^{10,40}$, as well as partially and fully oxidized graphene (Methods, Supplementary Fig. 1e).

Figure 3 shows the volcano plots for $2 \mathrm{e}^{-}$water oxidation for the considered structures as a function of the $\Delta \mathrm{G} * \mathrm{OH}$. The active site models used in this work span a wide range of catalytic activities on both sides of the volcano. We postulate here that slight modulations of the ${ }^{*} \mathrm{OH}$ binding energy, arising from those trapped $\mathrm{O}_{2}$ gas bubbles, can lead to significant improvements in $\mathrm{H}_{2} \mathrm{O}_{2}$ activity and selectivity. Two possible effects of the $\mathrm{O}_{2}$ gas bubbles are as follows; firstly, the solvation stabilization may be decreased, since the presence of $\mathrm{O}_{2}$ gas molecules interrupts hydrogen bonding networks and therefore reduces the average number of possible hydrogen bonds ${ }^{41}$. In aqueous solution, it has been experimentally and theoretically reported that adsorbed $* \mathrm{OH}$ is stabilized by 0.4 $0.8 \mathrm{eV}$ by hydrogen bonding interactions with nearby $\mathrm{H}_{2} \mathrm{O}$ molecules ${ }^{42-44}$. By using a combination of explicit and implicit solvation approach ${ }^{45}$, we found a solvation stabilization effect up of around $0.3 \mathrm{eV}$ (Supplementary Table 1) which lies at the bottom 
of the previously reported range. Although this value may vary depending on the surface and external conditions such as potential and $\mathrm{pH}$, we generally expect the ${ }^{*} \mathrm{OH}$ binding to be weakened due to missing hydrogen bonding networks, which will shift the less oxidized defected active sites (yellow and light green symbols in Fig. 3d) towards the activity peak of the volcano plot.

Secondly, the reduced local $\mathrm{H}_{2} \mathrm{O}$ concentration near the surface due to the trapped $\mathrm{O}_{2}$ bubbles can lead to a decrease of the oxidation of the graphene surfaces, which in turn weakens $* \mathrm{OH}$ binding. This was confirmed by operando Raman spectroscopy that, under water oxidation reaction conditions the CFP-60\% showed less oxidized surface than that of pristine CFP (Supplementary Fig. 10). The strong electrochemical driving force to generate $* \mathrm{O}$ coverage from $\mathrm{H}_{2} \mathrm{O}$, makes this process highly sensitive to the water chemical potential. On the other hand, $\mathrm{O}_{2}$ chemical dissociation plays only a minor role even if large $\mathrm{O}_{2}$ pressures are present inside the bubbles, due to the relatively small thermochemical driving force compared to water oxidation (Supplementary Fig. 11) and the high $\mathrm{O}_{2}$ chemical dissociation barrier $(>2 \mathrm{eV})^{46,47}$. It is thus the presence of $\mathrm{H}_{2} \mathrm{O}$ molecules under the influence of a high electrochemical potential (2 - $3 \mathrm{~V}$ vs. RHE) which leads to a significant oxidization of the carbon material. Our surface Pourbaix analysis (Supplementary Fig. 12 and 13) of all structures shows that it is thermodynamically favorable to completely saturate the surface with oxygen. In the steady state, however, the surface might not be fully oxidized due to significant kinetic barriers for surface to subsurface $\mathrm{O}$ diffusion $(>4 \mathrm{eV})^{48}$. This leads to free active sites where ${ }^{*} \mathrm{OH}$ can bind surrounded by a highly oxidized carbon environment. A high degree of oxidation localizes the $* \mathrm{OH}$ binding energy at the right, weak-binding leg of the volcano (Fig. 3d). 
Consequently, a decrease in the $\mathrm{H}_{2} \mathrm{O}$ concentration inside the $\mathrm{O}_{2}$ bubbles and the corresponding decrease in surface oxidation would shift such sites to stronger * $\mathrm{OH}$ binding and higher $\mathrm{H}_{2} \mathrm{O}_{2}$ activity (Supplementary Fig. 14). Based on both the experimental and theoretical investigations, we conclude that the specific properties of the PTFE-CFP systems lead to less oxidized surfaces as well as water-poor regions in the created $\mathrm{O}_{2}$ bubbles which could both shift the ${ }^{*} \mathrm{OH}$ binding energy of active sites to the top of the volcano thereby improving $\mathrm{H}_{2} \mathrm{O}_{2}$ activity, as summarized in the schematic diagram in

\section{Supplementary Fig. 15.}

a

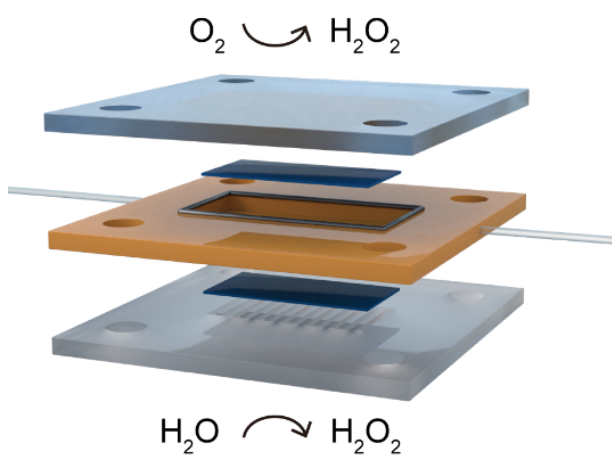

C

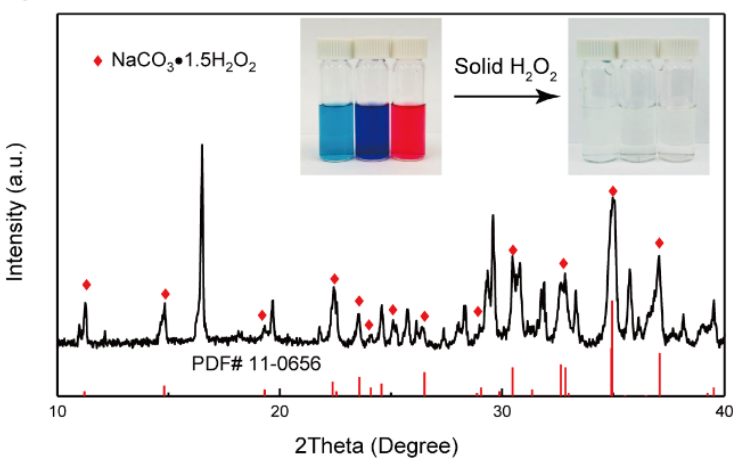

b

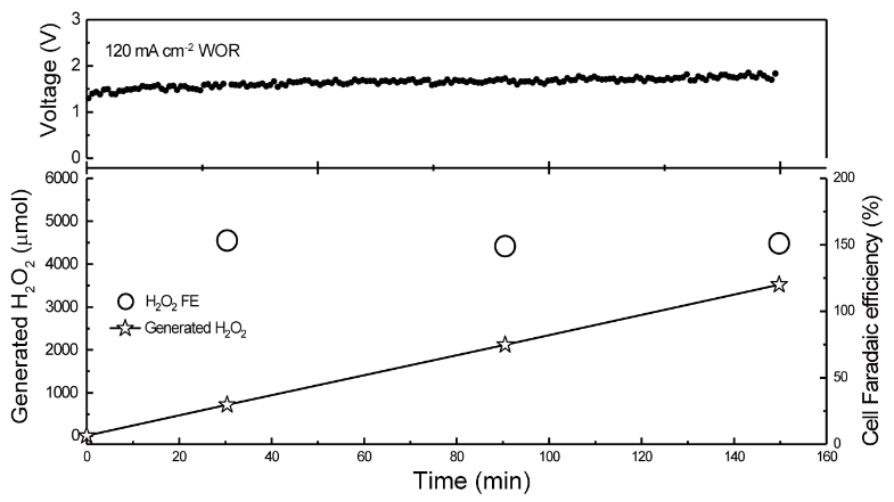

d

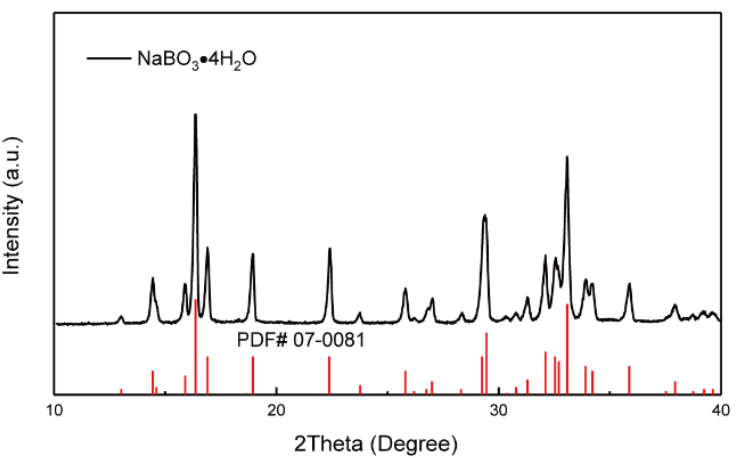

Fig. 4 | Applications of developed 2e-WOR//2e-ORR $\mathrm{H}_{2} \mathrm{O}_{2}$ electrosynthetic cell. a, schematic design of our $\mathrm{H}_{2} \mathrm{O}_{2}$ production protype cell. $\mathbf{b}, \mathrm{H}_{2} \mathrm{O}_{2}$ generation performance of our $2 \mathrm{e}^{-}-\mathrm{ORR} / / 2 \mathrm{e}^{-}$-WOR cell, which demonstrates an electricity-to- $\mathrm{H}_{2} \mathrm{O}_{2}$ efficiency of $90 \%$, making it highly competitive to traditional anthraquinone oxidation technology. c, XRD pattern for as-extracted solid $\mathrm{H}_{2} \mathrm{O}_{2}$ from electrolyte after electrolysis $\left(\mathrm{Na}_{2} \mathrm{CO}_{3}+1.5 \mathrm{H}_{2} \mathrm{O}_{2}\right.$ $\rightarrow \mathrm{Na}_{2} \mathrm{CO}_{3} \cdot 1.5 \mathrm{H}_{2} \mathrm{O}_{2}$ ). The red rhombus symbol represents the peaks which originates from 
$\mathrm{Na}_{2} \mathrm{CO}_{3} \cdot 1.5 \mathrm{H}_{2} \mathrm{O}_{2}$ (PDF no. 11-0656). All other peaks can be ascribed to hydrated $\mathrm{Na}_{2} \mathrm{CO}_{3}$ $\left(\mathrm{Na}_{2} \mathrm{CO}_{3} \cdot \mathrm{H}_{2} \mathrm{O}\right.$ and $\left.\mathrm{Na}_{2} \mathrm{CO}_{3} \cdot 7 \mathrm{H}_{2} \mathrm{O}\right)$. Inset of figure $\mathbf{c}$ shows the dye degradation using aged solid $\mathrm{H}_{2} \mathrm{O}_{2}$ which was stored under ambient conditions for two months, highlighting the stability and reliability of solid $\mathrm{H}_{2} \mathrm{O}_{2}$ compared to liquid $\mathrm{H}_{2} \mathrm{O}_{2}$. The color image shows the pristine dye solution. The transparent one is the dye solution after reaction with solid $\mathrm{H}_{2} \mathrm{O}_{2}$.d, XRD pattern for as-obtained sodium perborate $\left(\mathrm{Na}_{2} \mathrm{BO}_{3} \cdot 4 \mathrm{H}_{2} \mathrm{O}\right)$, demonstrating the successful synthesis of pure high-value-added sodium perborate.

$\mathrm{H}_{2} \mathrm{O}_{2}$ electrosynthetic cell. This high-performance $2 \mathrm{e}^{-}-$WOR catalyst, when coupled with an active and selective $2 \mathrm{e}^{-}-\mathrm{ORR}$ cathode ${ }^{9,10}$, can enable a highly efficient $\mathrm{H}_{2} \mathrm{O}_{2}$ electrosynthetic cell where $\mathrm{H}_{2} \mathrm{O}_{2}$ can be selectively generated from both electrodes. In contrast to previous $4 \mathrm{e}^{-}-\mathrm{WOR} / / 2 \mathrm{e}^{-}-\mathrm{ORR}$ systems where the maximal $\mathrm{H}_{2} \mathrm{O}_{2} \mathrm{FE}_{\text {cell }}$ was defined as $100 \%{ }^{15}$, our $2 \mathrm{e}^{-}-\mathrm{WOR} / / 2 \mathrm{e}^{-}-\mathrm{ORR}$ system can reach to a maximal $\mathrm{H}_{2} \mathrm{O}_{2} \mathrm{FE}_{\text {cell }}$ of $200 \%$ (Methods), as two electrons shuttled from anode to cathode can maximally produce two $\mathrm{H}_{2} \mathrm{O}_{2}$ molecules. Here we demonstrate a membrane-free $\mathrm{H}_{2} \mathrm{O}_{2}$ electrocatalytic generation flow-cell with the state-of-the-art $\mathrm{H}_{2} \mathrm{O}_{2}$ generation rate and efficiency (Fig. 4a, Methods). Oxidized carbon nanotube ${ }^{10}$ was employed as an efficient and stable $2 \mathrm{e}^{-}$-ORR catalyst (Supplementary Fig. 16) to couple with our CFP-60\% anode. Only $c a .1 .7 \mathrm{~V}_{\text {cell }}$ was required to reach a cell current of $50.4 \mathrm{~mA}\left(120 \mathrm{~mA} \mathrm{~cm}^{-2}\right.$ WOR $)$ in our $2 \mathrm{e}^{-}-\mathrm{WOR} / / 2 \mathrm{e}^{-}$ -ORR cell (Fig. 4b, Methods), delivering a $\mathrm{H}_{2} \mathrm{O}_{2} \mathrm{FE}_{\text {cell }}$ of $153 \%$. This result agrees well with $\mathrm{H}_{2} \mathrm{O}_{2}$ selectivity on WOR $(\sim 60 \%)$ and ORR $(\sim 90 \%)$ catalysts when tested individually in standard three-electrode setup. An impressive $\mathrm{H}_{2} \mathrm{O}_{2}$ production rate of 24 $\mu \mathrm{mol} \mathrm{min}{ }^{-1}$ was achieved in our electrosynthetic cell. This extraordinary current efficiency makes the electrochemical $\mathrm{H}_{2} \mathrm{O}_{2}$ synthesis cell highly competitive relative to energydemanding anthraquinone cycling (Supplementary Note 1). This onsite $\mathrm{H}_{2} \mathrm{O}_{2}$ flow generation opens up opportunities in a wide range of practical applications ${ }^{49}, e . g$. domestic 
sewage treatment. We showed a representative demonstration here where by feeding the continuously produced $\mathrm{H}_{2} \mathrm{O}_{2}$ solution, the organic contamination in water can be rapidly degraded (Supplementary Fig. 17a and Supplementary Video 4). Furthermore, to minimize the transportation and storage cost of liquid $\mathrm{H}_{2} \mathrm{O}_{2}$, solid $\mathrm{H}_{2} \mathrm{O}_{2}$ powder - an adduct product between $\mathrm{Na}_{2} \mathrm{CO}_{3}$ and $\mathrm{H}_{2} \mathrm{O}_{2}\left(\mathrm{Na}_{2} \mathrm{CO}_{3} \cdot 1.5 \mathrm{H}_{2} \mathrm{O}_{2}\right)^{50}$ - was directly extracted from the $\mathrm{Na}_{2} \mathrm{CO}_{3}$ electrolyte after a continuous electrolysis (Supplementary Fig. 17b, Methods). Both X-ray diffraction (XRD) and XPS analysis (Fig. 4c and Supplementary Fig. 18) confirmed the successful preparation of solid $\mathrm{H}_{2} \mathrm{O}_{2}$, which is more stable and reliable than liquid $\mathrm{H}_{2} \mathrm{O}_{2} .{ }^{50}$ We showed that the solid $\mathrm{H}_{2} \mathrm{O}_{2}$ powders were still highly active for organic dye degradation after two months storage under ambient conditions (Fig. 4c and Supplementary Video 5). Meanwhile, we demonstrated that other high-value products, e.g. sodium perborate (Fig. $\mathbf{4 d}$ ), can be in-situ generated and precipitated out by simply adding sodium metaborate into the electrolyte.

\section{Conclusions}

Taken together, our experimental and theoretical results demonstrate the efficacy of our catalyst design concept, that accumulated local gaseous $\mathrm{O}_{2}$ can shift the energetics of the water oxidation reaction in favor of $2 \mathrm{e}^{-}$of $\mathrm{H}_{2} \mathrm{O}_{2}$ generation. Future studies will be directed towards more uniform and stable coating of hydrophobic materials to further boost the local $\mathrm{O}_{2}$ concentration and prevent wetting after long-term operation. Additionally, our investigations on Ni suggest that higher activity and selectivity can be achieved by applying this concept on known $\mathrm{H}_{2} \mathrm{O}-$ to- $\mathrm{H}_{2} \mathrm{O}_{2}$ catalysts. Fine characterizations on crystalline 
catalysts will further allow computational simulations to study the mechanism and the origin of improvement in catalytic performances in detail.

\section{References}

1 Perry, S. C. et al. Electrochemical synthesis of hydrogen peroxide from water and oxygen. Nature Reviews Chemistry, 3, 442-458 (2019).

2 Shen, R. et al. High-Concentration Single Atomic Pt Sites on Hollow CuSx for Selective $\mathrm{O}_{2}$ Reduction to $\mathrm{H}_{2} \mathrm{O}_{2}$ in Acid Solution. Chem 5, 2009-2110 (2019).

3 Campos-Martin, J. M., Blanco-Brieva, G. \& Fierro, J. L. Hydrogen peroxide synthesis: an outlook beyond the anthraquinone process. Angewandte Chemie International Edition 45, 6962-6984 (2006).

4 Kuttassery, F. et al. One Electron-Initiated Two-Electron Oxidation of Water by Aluminum Porphyrins with Earth's Most Abundant Metal. Chemsuschem 10, 19091915 (2017).

5 Remello, S. N. et al. Two-electron oxidation of water to form hydrogen peroxide catalysed by silicon-porphyrins. Sustainable Energy \& Fuels 2, 1966-1973 (2018).

6 Mathew, S. et al. Two-Electron Oxidation of Water Through One-Photon Excitation of Aluminium Porphyrins: Molecular Mechanism and Detection of Key Intermediates. ChemPhotoChem 2, 240-248 (2018).

7 Yang, S. et al. Toward the decentralized electrochemical production of $\mathrm{H}_{2} \mathrm{O}_{2}$ : a focus on the catalysis. ACS Catalysis 8, 4064-4081 (2018).

8 Edwards, J. K. \& Hutchings, G. J. Palladium and gold-palladium catalysts for the direct synthesis of hydrogen peroxide. Angewandte Chemie International Edition 47, 9192-9198 (2008).

9 Kim, H. W. et al. Efficient hydrogen peroxide generation using reduced graphene oxide-based oxygen reduction electrocatalysts. Nature Catalysis 1, 282 (2018).

$10 \mathrm{Lu}, \mathrm{Z}$. et al. High-efficiency oxygen reduction to hydrogen peroxide catalysed by oxidized carbon materials. Nature Catalysis 1, 156 (2018).

11 Siahrostami, S. et al. Enabling direct $\mathrm{H}_{2} \mathrm{O}_{2}$ production through rational electrocatalyst design. Nature materials 12, 1137 (2013).

12 Izgorodin, A., Izgorodina, E. \& MacFarlane, D. R. Low overpotential water oxidation to hydrogen peroxide on a MnOx catalyst. Energ Environ Sci 5, 94969501 (2012).

13 Shi, X. et al. Understanding activity trends in electrochemical water oxidation to form hydrogen peroxide. Nat Commun 8, 701 (2017).

14 Kelly, S. et al. ZnO as an Active and Selective Catalyst for Electrochemical Water Oxidation to Hydrogen Peroxide. ACS Catalysis 9, 4593-4599 (2019).

15 Han, L. et al. In-Plane Carbon Lattice-Defect Regulating Electrochemical Oxygen Reduction to Hydrogen Peroxide Production over Nitrogen-Doped Graphene. ACS Catalysis 9, 1283-1288 (2019). 
16 Zhao, K. et al. Enhanced $\mathrm{H}_{2} \mathrm{O}_{2}$ production by selective electrochemical reduction of $\mathrm{O}_{2}$ on fluorine-doped hierarchically porous carbon. J Catal 357, 118-126 (2018).

17 Jiang, Y. et al. Selective Electrochemical $\mathrm{H}_{2} \mathrm{O}_{2}$ Production through Two-Electron Oxygen Electrochemistry. Adv Energy Mater 8, 1801909 (2018).

18 Fuku, K., Miyase, Y., Miseki, Y., Gunji, T. \& Sayama, K. Enhanced oxidative hydrogen peroxide production on conducting glass anodes modified with metal oxides. Chemistryselect 1, 5721-5726 (2016).

19 Kanan, M. W. \& Nocera, D. G. In situ formation of an oxygen-evolving catalyst in neutral water containing phosphate and $\mathrm{Co}^{2+}$. Science 321, 1072-1075 (2008).

20 Finke, C. E. et al. Enhancing the activity of oxygen-evolution and chlorineevolution electrocatalysts by atomic layer deposition of $\mathrm{TiO}_{2}$. Energ Environ Sci 12, 358-365 (2019).

21 Song, F. \& Hu, X. Exfoliation of layered double hydroxides for enhanced oxygen evolution catalysis. Nat Commun 5, 4477 (2014).

22 Suntivich, J., May, K. J., Gasteiger, H. A., Goodenough, J. B. \& Shao-Horn, Y. A perovskite oxide optimized for oxygen evolution catalysis from molecular orbital principles. Science 334, 1383-1385 (2011).

23 McCrory, C. C., Jung, S., Peters, J. C. \& Jaramillo, T. F. Benchmarking heterogeneous electrocatalysts for the oxygen evolution reaction. J Am Chem Soc 135, 16977-16987 (2013).

24 Zhang, B. et al. Homogeneously dispersed multimetal oxygen-evolving catalysts. Science 352, 333-337 (2016).

25 Zheng, X. et al. Theory-driven design of high-valence metal sites for water oxidation confirmed using in situ soft X-ray absorption. Nat Chem 10, 149 (2018).

26 Viswanathan, V., Hansen, H. A. \& Nørskov, J. K. Selective electrochemical generation of hydrogen peroxide from water oxidation. The journal of physical chemistry letters 6, 4224-4228 (2015).

27 Park, S. Y. et al. $\mathrm{CaSnO}_{3}$ : An Electrocatalyst for Two-Electron Water Oxidation Reaction to Form H2O2. ACS Energy Letters 4, 352-357 (2018).

$28 \mathrm{Xu}, \mathrm{W} ., \mathrm{Lu}, \mathrm{Z}$., Wan, P., Kuang, Y. \& Sun, X. High-Performance Water Electrolysis System with Double Nanostructured Superaerophobic Electrodes. Small 12, 2492-2498 (2016).

29 Lu, Z. et al. Superaerophilic carbon-nanotube-array electrode for high-performance oxygen reduction reaction. Advanced Materials 28, 7155-7161 (2016).

30 Yu, C., Zhang, P., Wang, J. \& Jiang, L. Superwettability of Gas Bubbles and Its Application: From Bioinspiration to Advanced Materials. Advanced Materials 29, 1703053 (2017).

31 Kim, K.-W., Kuppuswamy, M. \& Savinell, R. Electrochemical oxidation of benzene at a glassy carbon electrode. Journal of applied electrochemistry 30, 543549 (2000).

32 Lv, K. et al. Hydrophobic and Electronic Properties of the E-MoS 2 Nanosheets Induced by FAS for the $\mathrm{CO}_{2}$ Electroreduction to Syngas with a Wide Range of $\mathrm{CO} / \mathrm{H}_{2}$ Ratios. Advanced Functional Materials 28, 1802339 (2018).

33 Tang, C., Cheng, N., Pu, Z., Xing, W. \& Sun, X. NiSe nanowire film supported on nickel foam: an efficient and stable 3D bifunctional electrode for full water splitting. Angewandte Chemie International Edition 54, 9351-9355 (2015). 
34 Wang, J., Zhong, H. x., Qin, Y. 1. \& Zhang, X. b. An Efficient Three-Dimensional Oxygen Evolution Electrode. Angewandte Chemie International Edition 52, 52485253 (2013).

35 Park, S. Y. et al. $\mathrm{CaSnO}_{3}$ : An Electrocatalyst for 2-Electron Water Oxidation Reaction to Form $\mathrm{H}_{2} \mathrm{O}_{2}$. ACS Energy Letters 4, 352-357 (2018).

36 Fuku, K. \& Sayama, K. Efficient oxidative hydrogen peroxide production and accumulation in photoelectrochemical water splitting using a tungsten trioxide/bismuth vanadate photoanode. Chem Commun 52, 5406-5409 (2016).

37 Shi, X., Zhang, Y., Siahrostami, S. \& Zheng, X. Light-Driven BiVO $4-C$ Fuel Cell with Simultaneous Production of $\mathrm{H}_{2} \mathrm{O}_{2}$. Adv Energy Mater 8, 1801158 (2018).

38 Coplen, T. B. Normalization of oxygen and hydrogen isotope data. Chemical Geology: Isotope Geoscience Section 72, 293-297 (1988).

39 Harris, P. Fullerene-related structure of commercial glassy carbons. Philosophical Magazine 84, 3159-3167 (2004).

40 Chen, S. et al. Defective Carbon-Based Materials for the Electrochemical Synthesis of Hydrogen Peroxide. ACS Sustainable Chemistry \& Engineering 6, 311-317 (2017).

41 Siahrostami, S. \& Vojvodic, A. Influence of adsorbed water on the oxygen evolution reaction on oxides. The Journal of Physical Chemistry C 119, 1032-1037 (2014).

42 Casalongue, H. S. et al. Direct observation of the oxygenated species during oxygen reduction on a platinum fuel cell cathode. Nature communications 4, 2817 (2013).

43 Karlberg, G. \& Wahnström, G. Density-functional based modeling of the intermediate in the water production reaction on $\mathrm{Pt}$ (111). Physical review letters 92, 136103 (2004).

44 Patel, A. M. et al. Theoretical Approaches to Describing the Oxygen Reduction Reaction Activity of Single Atom Catalysts. The Journal of Physical Chemistry C 122, 29307-29318 (2018).

45 Mathew, K., Sundararaman, R., Letchworth-Weaver, K., Arias, T. \& Hennig, R. G. Implicit solvation model for density-functional study of nanocrystal surfaces and reaction pathways. The Journal of chemical physics 140, 084106 (2014).

46 Yan, H., Xu, B., Shi, S. \& Ouyang, C. First-principles study of the oxygen adsorption and dissociation on graphene and nitrogen doped graphene for Li-air batteries. Journal of Applied Physics 112, 104316 (2012).

47 Ni, S., Li, Z. \& Yang, J. Oxygen molecule dissociation on carbon nanostructures with different types of nitrogen doping. Nanoscale 4, 1184-1189 (2012).

48 He, G., Liang, T., Wang, Q., Xu, M. \& Liu, Y. Increased permeability of oxygen atoms through graphene with ripples. Soft matter 13, 3994-4000 (2017).

49 Yang, S. et al. Toward the decentralized electrochemical production of $\mathrm{H}_{2} \mathrm{O}_{2}$ : a focus on the catalysis. ACS Catalysis 8, 4064-4081 (2018).

50 McKillop, A. \& Sanderson, W. R. Sodium perborate and sodium percarbonate: further applications in organic synthesis. Journal of the Chemical Society, Perkin Transactions 1, 471-476 (2000).

51 Jiang, K. et al. Transition-metal single atoms in a graphene shell as active centers for highly efficient artificial photosynthesis. Chem 3, 950-960 (2017). 
52 Han, N. et al. Nitrogen-doped tungsten carbide nanoarray as an efficient bifunctional electrocatalyst for water splitting in acid. Nat Commun 9, 924 (2018).

53 Kresse, G. \& Joubert, D. From ultrasoft pseudopotentials to the projector augmented-wave method. Physical Review B 59, 1758 (1999).

54 Kresse, G. \& Furthmüller, J. Efficiency of ab-initio total energy calculations for metals and semiconductors using a plane-wave basis set. Computational materials science 6, 15-50 (1996).

55 Wellendorff, J. et al. Density functionals for surface science: Exchange-correlation model development with Bayesian error estimation. Physical Review B 85, 235149 (2012).

56 Blöchl, P. E. Projector augmented-wave method. Physical review B 50, 17953 (1994).

57 Nørskov, J. K. et al. Origin of the overpotential for oxygen reduction at a fuel-cell cathode. The Journal of Physical Chemistry B 108, 17886-17892 (2004).

\section{Methods}

Preparation of PTFE patterned glassy carbon. The shadow mask patterns are designed from CircuitMaster software. Polyimide substrate was pinned through a vacuum environment and LPFK Protolaser U3 ( $\mathrm{f}=103 \mathrm{~mm}, \lambda=355 \mathrm{~nm}$ ) was used to fabricate the polyimide shadow mask through direct laser engraving. Then, $1 \mathrm{~mL}$ of $60 \%$ polytetrafluoroethylene (PTFE) aqueous solution (Sigma) was spray-coated onto the glassy carbon (HTW GmbH) surface with the help of the polyimide shadow mask to obtain the well-defined PTFE patterns. After drying at $120{ }^{\circ} \mathrm{C}$ under ambient condition, the PTFE patterned glassy carbon samples were annealed at $350^{\circ} \mathrm{C}$ under Argon atmosphere for 30 minutes to obtain a superaerophilic surface to accumulate the locally produced $\mathrm{O}_{2}$.

Preparation of PTFE decorated CFP. $190 \mu \mathrm{m}$-thick CFP (Fuel Cell Store) was pretreated by oxygen plasma ( $50 \mathrm{~W}, 2$ minutes) to create a hydrophilic surface. Then, $2 \times 5$ $\mathrm{cm}^{2}$ as-treated CFP was soaked into $60 \%(5 \%$ or $20 \%)$ PTFE aqueous solution for 10 minutes and then dried at $120{ }^{\circ} \mathrm{C}$ under ambient condition. Note that the $5 \%$ and $20 \%$ PTFE solutions are diluted from $60 \%$ PTFE. Next, the PTFE loaded CFP samples were annealed at $350{ }^{\circ} \mathrm{C}$ under Argon atmosphere for 30 minutes to obtain a superaerophilic surface to accumulate the locally produced $\mathrm{O}_{2}$. The mass loadings of PTFE (mass different before and after surface modification) for CFP-5\%, CFP- $20 \%$ and CFP- $60 \%$ are $c a .12 \%, 55 \%$ and $150 \%$, respectively.

Preparation of FAS decorated CFP. $190 \mu \mathrm{m}$-thick CFP was pre-treated by oxygen plasma (50 W, 10 minutes) in order to introduce hydrophilic functional groups. Then, trimethoxy $(1 \mathrm{H}, 1 \mathrm{H}, 2 \mathrm{H}, 2 \mathrm{H}$-heptadecafluorodecyl) silane (FAS) was used as the chemical vapor deposition material to increase the gas adhesive force of CFP, which was carried out in a beaker that contained FAS/ethanol solution $(80 \mu \mathrm{L}: 4 \mathrm{~mL}$ in volume) in equilibrium with its vapor. The plasma treated electrode was exposed to FAS vapor for $30 \mathrm{hr}$ under ambient condition to receive aerophilic CFP-FAS electrode. 
Preparation of control samples. $\mathrm{O}_{2}$ plasma treated CFP sample was prepared by $50 \mathrm{~W}$ oxygen plasma functionalization for 2 minutes. The pristine CFP was calcinated at $350{ }^{\circ} \mathrm{C}$ under Argon atmosphere for 30 minutes to obtain Argon annealed sample. The CFP- $60 \%$ electrode was annealed at $900^{\circ} \mathrm{C}$ under Argon atmosphere for $1 \mathrm{hr}$ in order to fabricate the fluorine-doped carbon/CFP electrode.

Preparation of oxidized carbon material for oxygen reduction. The oxidized carbon nanotube was prepared according to previous report. ${ }^{10}$

Electrocatalytic oxidation of $\mathrm{H}_{2} \mathrm{O}$. The electrochemical measurements were run at $25^{\circ} \mathrm{C}$ in a customized gastight H-type glass cell separated by Nafion 117 membrane (Fuel Cell Store). A BioLogic VMP3 workstation was employed to record the electrochemical response. In a typical three-electrode system, a platinum foil (Beantown Chemical, $99.99 \%$ ) and a saturated calomel electrode (SCE, CH Instruments) were used as the counter and reference electrode, respectively. The carbon electrodes (pristine and PTFE patterned glassy carbon; pristine and PTFE decorated CFP; $\sim 1 \mathrm{~cm}^{2}$ ) were used as the working electrodes. The backside of glassy carbon was covered by an electrochemically inert, hydrophobic wax (Apiezon wax WW100) during electrochemical tests. Before electrochemical measurements, all samples were pre-stabilized at $1.2 \mathrm{~V} v s$. SCE to achieve a stable current density in $1.0 \mathrm{M} \mathrm{Na}_{2} \mathrm{CO}_{3}$ electrolyte. All potentials measured against $\mathrm{SCE}$ was converted to the reversible hydrogen electrode (RHE) scale in this work using $\mathrm{E}_{\mathrm{RHE}}=$ $\mathrm{E}_{\mathrm{SCE}}+0.244 \mathrm{~V}+0.0591 \times \mathrm{pH}$, where $\mathrm{pH}$ values of electrolytes were determined by Orion 320 PerpHecT LogR Meter (Thermo Scientific). $1.0 \mathrm{M} \mathrm{Na}_{2} \mathrm{CO}_{3}$ aqueous solution was used as electrolyte in our study with $\mathrm{pH}$ of 11.96 . Note that $4 \mathrm{mg} \mathrm{mL}^{-1} \mathrm{Na}_{2} \mathrm{SiO}_{3}$ (Sigma) was added into electrolyte to stabilize the formed $\mathrm{H}_{2} \mathrm{O}_{2}$ during stability measurements. The electrolyte in the anodic compartment was stirred at a rate of 1000 r.p.m. during electrolysis. Solution resistance (Rs) was determined by potentiostatic electrochemical impedance spectroscopy (PEIS) at frequencies ranging from $0.1 \mathrm{~Hz}$ to $200 \mathrm{kHz}$. All the measured potentials were manually compensated unless stated otherwise.

After electrolysis with $10 \sim 50 \mathrm{C}$ passing, the generated $\mathrm{H}_{2} \mathrm{O}_{2}$ concentration was firstly roughly detected by using the standard $\mathrm{H}_{2} \mathrm{O}_{2}$ strips (Indigo Instruments), and further confirmed using standard potassium permanganate $\left(0.1 \mathrm{~N} \mathrm{KMnO}_{4}\right.$ solution, Sigma-Aldrich $)$ titration process, according to following equation:

$$
2 \mathrm{MnO}_{4}^{-}+5 \mathrm{H}_{2} \mathrm{O}_{2}+6 \mathrm{H}^{+} \rightarrow 6 \mathrm{Mn}^{2+}+5 \mathrm{O}_{2}+8 \mathrm{H}_{2} \mathrm{O}
$$

In this work, sulfuric acid ( $2.0 \mathrm{~N} \mathrm{H}_{2} \mathrm{SO}_{4}$, VWR) was used as the $\mathrm{H}^{+}$source. The Faradaic efficiency ( $\mathrm{FE}$ ) for $\mathrm{H}_{2} \mathrm{O}_{2}$ production is calculated using following equation:

$$
\mathrm{FE}=\frac{\text { generated } \mathrm{H}_{2} \mathrm{O}_{2}(\mathrm{~mol}) \times 2 \times 96485}{\text { total amount of charge passed (C) }} * 100(\text { maximum } 100 \%)
$$

In order to quantify the gas products during electrolysis, Argon gas (Airgas, 99.995 \%) was delivered into the anodic compartment at a rate of 20.0 standard cubic centimeters per minute (sccm, monitored by Alicat Scientific mass flow controller) and vented into a gas chromatograph (Shimadzu gas chromatography-2014) equipped with a combination of molecular sieve $5 \AA$, Hayesep Q, Hayesep T, and Hayesep N columns. A thermal conductivity detector (TCD) was mainly used to quantify gas product concentration. The partial current density for produced $\mathrm{O}_{2}$ was calculated as below: 


$$
\mathrm{j}_{\mathrm{i}}=\mathrm{x}_{\mathrm{i}} \times \mathrm{v} \times \frac{\mathrm{n}_{\mathrm{i}} \mathrm{Fp}^{\mathrm{o}}}{\mathrm{RT}} \times(\text { electrode area })^{-1}
$$

where $\mathrm{x}_{\mathrm{i}}$ is the volume fraction of certain product determined by online gas chromatography referenced to calibration curves from the standard gas sample (Airgas), $\mathrm{v}$ is the flow rate of $20 \mathrm{sccm}, \mathrm{n}_{\mathrm{i}}$ is the number of electrons involved, $\mathrm{p}^{\mathrm{o}}=101.3 \mathrm{kPa}, \mathrm{F}$ is the Faradaic constant, $\mathrm{T}=298 \mathrm{~K}$ and $\mathrm{R}$ is the gas constant. The corresponding Faradaic efficiency at each potential is calculated by $\frac{\mathrm{j}_{\mathrm{i}}}{\mathrm{j}_{\text {overall }}} \times 100$.

For the $2 \mathrm{e}^{-}-\mathrm{WOR} / / 2 \mathrm{e}^{-}-\mathrm{ORR}$ electrosynthetic cell test, $0.5 \mathrm{mg} \mathrm{cm}{ }^{-2}$ oxidized carbon nanotube catalyst was air-brushed onto $2 \mathrm{~cm}^{2}$ Sigracet $35 \mathrm{BC}$ GDL (Fuel Cell Store) electrodes as $2 \mathrm{e}^{-}-\mathrm{ORR}$ cathode. And, $0.42 \mathrm{~cm}^{2} \mathrm{CFP}-60 \%$ electrode was used as anode. The two electrodes were therefore placed into opposite sides in the flow-cell ${ }^{51}$ without separation membrane. $\mathrm{O}_{2}$ saturated $1.0 \mathrm{M} \mathrm{Na}_{2} \mathrm{CO}_{3}$ with $4 \mathrm{mg} \mathrm{mL}^{-1} \mathrm{Na}_{2} \mathrm{SiO}_{3}$ was used as electrolyte. The cathode was open to the atmosphere. The flow rate of $1.0 \mathrm{M} \mathrm{Na}_{2} \mathrm{CO}_{3}$ electrolyte was $5 \mathrm{~mL} \mathrm{~min}^{-1}$ controlled by a peristaltic pump. A current of $50.4 \mathrm{~mA}$ was employed for $\mathrm{H}_{2} \mathrm{O}_{2}$ production. To extract the solid $\mathrm{H}_{2} \mathrm{O}_{2}$ from the electrolyte after electrolysis (three-electrode configuration, $25 \mathrm{~mL} 1.0 \mathrm{M} \mathrm{Na}_{2} \mathrm{CO}_{3}$ electrolyte, electrolysis at $2.4 \mathrm{~V} v s$. RHE at $5{ }^{\circ} \mathrm{C}$ for 5 days; the CFP- $60 \%$ catalyst was replaced using fresh catalyst after every $24 \mathrm{~h}$; Bipolar membrane was used to replace the Nafion 117; the cathode was coupled with two-electron ORR using oxidized carbon nanotube electrode), about $100 \mathrm{~mL}$ of absolute ethanol is added into $20 \mathrm{~mL}$ of the electrolyte, and the mixture is mechanically stirred. The precipitate is isolated by vacuum filtration and washed several times with absolute ethanol. The isolated precipitate is then dried in a vacuum oven at room temperature for $24 \mathrm{~h}$. For sodium perborate synthesis, a solution contains of $2.0 \mathrm{M} \mathrm{NaBO}_{2}$ and $1.0 \mathrm{M} \mathrm{Na}_{2} \mathrm{CO}_{3}$ was used as electrolyte. And the electrolysis was performed at a current density of $120 \mathrm{~mA} \mathrm{~cm}{ }^{-2}$ at $5{ }^{\circ} \mathrm{C}$. The in-situ formed white precipitate (sodium perborate) during electrolysis was collected for further characterizations.

The Faradaic efficiency of the electrosynthetic cell for $\mathrm{H}_{2} \mathrm{O}_{2}$ production and the corresponding electricity-to- $\mathrm{H}_{2} \mathrm{O}_{2}$ efficiency are calculated using following equations, respectively:

$$
\begin{gathered}
\qquad \mathrm{FE}_{\text {cell }}=\frac{\text { generated } \mathrm{H}_{2} \mathrm{O}_{2}(\mathrm{~mol}) \times 2 \times 96485}{\text { total amount of charge passed }(\mathrm{C})} * 100(\text { maximum } 200 \%) \\
\text { Electricity to } \mathrm{H}_{2} \mathrm{O}_{2} \text { efficiency }=\frac{\mathrm{E}_{2 \mathrm{e}-\mathrm{WOR}}-\mathrm{E}_{2 \mathrm{e}-\mathrm{ORR}}}{\mathrm{E}_{\text {cell }}} * \mathrm{FE}_{\text {cell }}(\text { maximum } 200 \%)
\end{gathered}
$$

where $\mathrm{E}_{2 \mathrm{e}-\text { WOR }}(1.76 \mathrm{~V})^{13}$ and $\mathrm{E}_{2 \mathrm{e}-\mathrm{ORR}}(0.76 \mathrm{~V})^{11}$ are the theoretical potential for twoelectron water oxidation and two-electron oxygen reduction, respectively. $\mathrm{E}_{\text {cell }}$ is the required cell voltage to offer a current density of $120 \mathrm{~mA} \mathrm{~cm}^{-2}$.

Characterization. Powder X-ray diffraction data were collected using a Bruker D2 Phaser diffractometer in parallel beam geometry employing $\mathrm{Cu} \mathrm{K \alpha}$ radiation $(\lambda=1.54056 \AA)$ and a 1-dimensional LYNXEYE detector, at a scan speed of $0.02^{\circ}$ per step and a holding time of $1 \mathrm{~s}$ per step. X-ray photoelectron spectroscopy was obtained with a Thermo Scientific $\mathrm{K}$-Alpha ESCA spectrometer, using a monochromatic Al Ka radiation (1486.6 eV) and a 
low energy flood gun as neutralizer. All XPS spectra were calibrated by shifting the detected carbon C 1s peak to $284.6 \mathrm{eV}$. SEM was performed on a Zeiss Supra55VP field emission scanning electron microscope with in-lens detector. The contact angles of $\mathrm{O}_{2}$ gas bubbles under electrolyte were tested by the method of captive bubble $e^{52}$ and the bubble size was controlled at $2 \mu \mathrm{L}$. Adhesive forces between the $\mathrm{O}_{2}$ bubbles and electrodes were assessed using Dataphysics DCAT21.

${ }^{18} \mathrm{O}$ isotope measurement. Firstly, $0.2 \mathrm{~mol}\left(21.2 \mathrm{~g}\right.$ ) $\mathrm{Na}_{2} \mathrm{CO}_{3}$ (Sigma) was dissolved into $200 \mathrm{~mL}$ ultrapure Milli-Q water. After stirring for $5 \mathrm{mins}, 25 \mathrm{~mL}$ of the fresh $1.0 \mathrm{M} \mathrm{Na}_{2} \mathrm{CO}_{3}$ solution was used as electrolyte for water oxidation. After electrolysis with $200 \mathrm{C}$ passing, $1 \mathrm{~mL}$ of the electrolyzed $1.0 \mathrm{M} \mathrm{Na}_{2} \mathrm{CO}_{3}$ solution was taken out, meanwhile another $1 \mathrm{~mL}$ of solution was taken from the unelectrolyzed bulk $1.0 \mathrm{M} \mathrm{Na}_{2} \mathrm{CO}_{3}$ solution. Then both of them were quickly dried (within 2 mins) in a surface dish at $100{ }^{\circ} \mathrm{C}$. Of note, the natural exchange time with the water was same for the unelectrolyzed and electrolyzed $\mathrm{Na}_{2} \mathrm{CO}_{3}$. Next, the dried $\mathrm{Na}_{2} \mathrm{CO}_{3}$ powder was collected for ${ }^{18} \mathrm{O}$ isotope analysis. Oxygen isotope analysis is performed on a Gas Bench-Conflo-Isotope Ratio Mass Spec (Delta V, ThermoScientific) system. $\sim 0.190 \mathrm{mg}$ Sodium carbonate $\left(\mathrm{Na}_{2} \mathrm{CO}_{3}\right)$ were weighed out into an exetainer, then was flushed by Helium flow for 10 minutes on Gas Bench. $0.3 \mathrm{ml} 105 \%$ phosphoric acid was added into the exetainer for 24 hour reaction. The generated $\mathrm{CO}_{2}$ gas was then delivered to mass spectrometry for isotope ratio analysis. Oxygen isotope composition of carbonate are calculated based on measured oxygen isotope composition of $\mathrm{CO}_{2}$ gas, based on the fractionation factor between the two at reaction temperature. Oxygen isotope values are reported in a delta notation, with respect to international standard, Vienna Standard Mean Ocean Water (VSMOW).

Operando Raman measurement. For operando electrochemical Raman spectroscopy measurements, a piece of carbon fiber paper $\left(1 \mathrm{~cm}^{2}\right.$, with or without PTFE treatment) was first stuck onto a polished glassy carbon electrode via a conductive carbon tape and then assembled into a homemade three electrode spectroelectrochemical cell. The Raman spectra were recorded on a Horiba LabRAM HR 800 confocal Raman microscopy, with the signals excited by a 532-nm Ventus VIS laser and collected by a 100x objective, at a dispersion grating of $600 \mathrm{~g} \mathrm{~mm}^{-1}$ and a co-adding of 64 scans. A Biological VSP potentiostat was used for potential control.

ECSA measurement. The ECSA was determined by measuring the capacitive current associated with double-layer charging from the scan-rate dependence of cyclic voltammetry $(\mathrm{CV})$. Before ECSA measurements, all samples were pre-stabilized at $1.2 \mathrm{~V}$ vs. SCE to achieve a stable current density in $1.0 \mathrm{M} \mathrm{Na}_{2} \mathrm{CO}_{3}$ electrolyte. By plotting the difference in current density $(j)$ between anodic and cathodic sweeps $(\Delta j)$ at a fixed potential against the scan rate, a linear trend is observed. The fitting slope is twice of the double-layer capacitance $\left(\mathrm{C}_{d l}\right)$, which is linearly promotional to the ECSA. These values of $\mathrm{C}_{d l}$ permit comparison of relative surface activity of different electrodes particularly in same electrolyte. To determine $\mathrm{C}_{d l}$ for various electrodes, the potential window of CVs was $0.15-0.25 \mathrm{~V} v s$. SCE with the scan rates from $50 \mathrm{mV} \mathrm{s}^{-1}$ to $150 \mathrm{mV} \mathrm{s}^{-1}$. Based on our previous work ${ }^{51}$, the double-layer capacitance of flat glassy carbon electrode is measured to be $c a .24 \mu \mathrm{F} \mathrm{cm}^{-2}$. Thus, the value of $24 \mu \mathrm{F} \mathrm{cm}^{-2}$ was used here for ECSA normalization. 
Computational methods. Density functional theory (DFT) calculations were performed using the Vienna Ab Initio Simulation Package (VASP) ${ }^{53,54}$ with BEEF-vdW exchangecorrelation functional ${ }^{55}$ and projector augmented-wave (PAW) pseudopotential ${ }^{56}$. The energy cutoff, a convergence criterion for self-consistent iteration and geometry relaxation were set to $500 \mathrm{eV}, 10^{-4} \mathrm{eV}$ and $0.05 \mathrm{eV} / \AA$, respectively. To simulate various carbon structures with a wide range of catalytic activities, we modelled four different structures (O-basal 1, O-basal 2, OH-basal and 5555-6-7777 defective) using $(6 \times 6)$ graphene, which have been shown to be active for $\mathrm{H}_{2} \mathrm{O}$ oxidation ${ }^{10,40}$. Additionally, we considered partially and fully oxidized graphene using $(1 \times 2)$ graphene. We added $15 \AA$ of vacuum layer to avoid non-physical interactions between repeating layers in z-direction. For large cells, a gamma point mesh was used, while for small oxidized graphene cells, $(6 \times 5 \times 1)$ meshes were used, which showed a negligible difference compared to $(12 \times 10 \times 1)$ meshes calculations. To test the effect of the implicit solvation, we used VASPsol with default parameter settings and a dielectric constant set to that of water $(\varepsilon=78.4)^{45}$.

At high applied overpotentials, the strongly oxidizing reaction conditions lead to carbon atoms being covered by adsorbed oxygen significantly affecting the catalytic properties. We therefore calculated binding free energies of $* \mathrm{O}(\Delta \mathrm{G} * \mathrm{O})$ on top and below the graphene sheet at different oxidation states referenced to free energies of $\mathrm{H}_{2}$ and $\mathrm{H}_{2} \mathrm{O}$ gas phase molecules. To investigate the effect of surface adsorbed ${ }^{*} \mathrm{O}$ on catalytic activity, we calculated $* \mathrm{O}$ coverage-dependent $* \mathrm{OH}$ binding free energies $(\Delta \mathrm{G} * \mathrm{OH})$, which is a key intermediate in electrochemical $\mathrm{H}_{2} \mathrm{O}$ oxidation to $\mathrm{H}_{2} \mathrm{O}_{2}{ }^{13}$.

To convert calculated electronic energies into free energies, we added free energy corrections for adsorbates which include zero-point energy, enthalpy and entropy at $300 \mathrm{~K}$ using the harmonic oscillator approximation. For gaseous molecules, we used the ideal gas approximation with the partial pressure of 101,325 $\mathrm{Pa}$ for $\mathrm{H}_{2}$, and 3,534 $\mathrm{Pa}$ for $\mathrm{H}_{2} \mathrm{O}$, which is the vapor pressure of $\mathrm{H}_{2} \mathrm{O}$. The effect of potential was included using the computational hydrogen electrode (CHE) method ${ }^{57}$, where the chemical potential of proton and electron pair equals to that of a half of hydrogen gas $\left(\mu\left(H^{+}+e^{-}\right)=1 / 2 \mu\left(H_{2}\right)\right)$ at standard conditions. As the potential is applied, the chemical potential of an electron is shifted by $-e U_{\text {elec }}$, where $e$ and $U_{\text {elec }}$ are elementary charge and electrode potential, respectively. 


\section{Data availability}

The data that support the plots within this paper and other findings of this study are available from the corresponding authors upon reasonable request.

\section{Competing interests}

All authors declare that they have no competing interests.

\section{Acknowledgements}

This work was supported by Rice University. H.W. is a CIFAR Azrieli Global Scholar in the Bio-inspired Solar Energy Program. C.X. acknowledges support from a J. Evans Attwell-Welch Postdoctoral Fellowship provided by the Smalley-Curl Institute. This work was performed in part at the Shared Equipment Authority (SEA) at Rice University. The authors acknowledge Lei Fan for the design of the scheme in Fig. 3. The authors also acknowledge Dr. Qiu Jiang, Dr. Tao Sun and Dr. Zhiyi Lu for their support to the experiment and useful discussions. K.C. acknowledges a grant (9455) from VILLUM FONDEN, and S.R. acknowledges funding from U.S. Department of Energy, Office of Science, Office of Basic Energy Sciences, Chemical Sciences, Geosciences, and Biosciences Division, Catalysis Science Program to the SUNCAT Center for Interface Science and Catalysis.

\section{Author contributions}

C.X. and H.W. conceptualized the project. H.W., K.C., and S.S. supervised the project. C.X. synthesized the catalysts. C.X. conducted the catalytic tests and the related data processing. C.X. performed materials characterization and analysis with the help of K.J., F.C. and X.S.. S.B. and S.R. performed the theoretical study. C.X. and H.W. wrote the manuscript with support from all authors. 